\title{
ANALYSIS OF FEDERAL OPTIONS TO SUPPORT PHOTOVOLTAIC INDUSTRY GROWTH
}

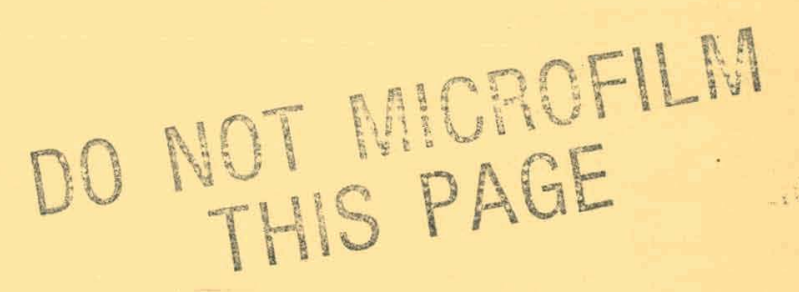




\section{DISCLAIMER}

This report was prepared as an account of work sponsored by an agency of the United States Government. Neither the United States Government nor any agency Thereof, nor any of their employees, makes any warranty, express or implied, or assumes any legal liability or responsibility for the accuracy, completeness, or usefulness of any information, apparatus, product, or process disclosed, or represents that its use would not infringe privately owned rights. Reference herein to any specific commercial product, process, or service by trade name, trademark, manufacturer, or otherwise does not necessarily constitute or imply its endorsement, recommendation, or favoring by the United States Government or any agency thereof. The views and opinions of authors expressed herein do not necessarily state or reflect those of the United States Government or any agency thereof. 


\section{DISCLAIMER}

Portions of this document may be illegible in electronic image products. Images are produced from the best available original document. 


\title{
Analysis of Federal Options to Support Photovoltaic Industry Growth
}

\author{
Acol-78csasity \\ Gennington \\ A. Cherdak \\ F. Williams \\ MTR- -79W00020 \\ DE83 016951
}

May 1979

\section{DISCLAIMER}

This report was prepared as an account of work sponsored by an agency of the United States Government. Neither the United States Government nor any agency thereof, nor any of their employees, makes any warranty, express or implied, or assumes any legal liability or responsibility for the accuracy, completeness, or usefulness of any information, apparatus, product, or process disclosed, or represents that its use would not infringe privately owned rights. Refer-

ence herein to any specific commercial product, process, or service by trade name, trademark, manufacturer, or otherwise does not necessarily constitute or imply its endorsement, recom-

I mendation, or favoring by the United States Government or any agency thereof. The views

and opinions of authors expressed herein do not necessarily state or reflect those of the

- United States Government or any agency thereof. 
THIS PAGE

\section{WAS INTENTIONALLY LEFT BLANK}


This report presents the methodology and results of an analysis to determine the impact and leverage of Federal options for supporting the growth of the photovoltaic industry. Results were projected for combinations of the following: an agressive Federal research and development program, achievement of a technological breakthrough, and immediate or breakthrough-dependent incentives including direct price reductions, keyed-to-breakeven subsidies, and Federal purchases. The modeling methodology and market assumptions were also tested to determine their effect on analysis results. 


\section{TABLE OF CONTENTS}

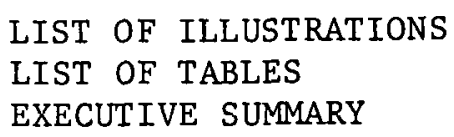

1.0 INTRODUCTION

2.0 SCOPE

2.1 Markets

2.2 Incentive Cases

2.3 Technology Development

3. 0 METHODOLOGY

3.1 Composition of Transition Markets

3.2 Composition of Mass Markets

3.3 Market Response

3.4 Photovoltaic System Assumptions

3.5 System S1ze

3.6 System Price

3.7 Collector Price.

3.8 Balance of System Prices

3.9 General Economic Assumptions

4.0 PHASE 1 ANALYSIS 
5.0 PHASE 2 ANALYSIS

5.2 Results 31

6.0 PHASE 3 - TESTING OF ASSUMPTIONS 37

6.1 Modeling Methodology $\quad 37$

6.2 Market Assumptions 39

APPENDIX A: ANALYSIS RESULTS A-1

APPENDIX B: MARKET DATA BASE B-1

APPENDIX C: INCENTIVE MECHANISMS C-1 
Metrek Market Share Function 13

Components of a Photovoltaic System

No Technology Breakthrough, Agressive Federal R\&D Program (Phase 1 Analysis, Cases $2 A$ and $B$ )

4 No Technology Breakthrough, No Federal R\&D Program (Phase 1 Analysis Cases $4 A$ and $B$ ) Federal R\&D (Phase 1 Analysis, Cases 1A, $B$ and C)

6 Technology Breakthrough, No Federal R\&D

Program (Phase 1 Analysis Cases 3A, B and $\mathrm{C}$ )

Phase 1 Incentive Cases and Options

\section{LIST OF. TABLES}

Table Number

Page

Transition Market Data and System Price

Market Potential and Suitability of

Residential and Commercial Buildings--

New Construction

III

Potential Photovoltaic Central Utility

Market

Figure of Merit by Market Sector

Balance of System Price Assumptions

22

Assumptions: Balance of Systems for

Transition Markets

$X$ Summary of Phase 2 Analysis--Non-, 
XIII Test of Assumptions--Commercial and

Utility Market Impact, No Incentives

XIV

Test of Assumptions--Commercial and

Utility Market Impact, No Breakthrough,

with Immediate Incentives

$\mathrm{XV}$

Test of Assumptions--SERI Markets,

Aggressive Federal R\&D, No Incentives,

No Breakthrough 
EXECUTIVE SUMMARY.

Photovoltaic systems provide a clean, simple method for the conversion of sunlight into electrical energy. The systems are silent and require no complex machinery; heat engine cycle, or intermediate conversion to heat.

However, the current costs of photovoltaic systems are high. As a result, photovoltaic sales are limited, and the existing industry for production of such systems is small.

This report presents the methodology and results of MITRE's analysis to determine the relative merit of various Federal options for supporting the growth of the photovoltaic industry.

The analysis was performed in three phases:

- Phase 1 consisted of a preliminary screening to identify the incentive cases with the greatest potential impact and leverage of Federal funds.

- Phase 2 consisted of a more detailed analysis of the three cases with the greatest potential.

- Phase 3 consisted of an analysis to determine how alternative assumptions would affect the results from Phases 1 and 2 .

MITRE's photovoltaic market response model was used in each phase of the analysis. The model utilizes a market share function to estimate the fraction of a potential market that may be captured by the photovoltaic industry. It is assumed that reductions in photovoltaic prices will result from increased cumulative production experience rather than price/time relationships. *

\footnotetext{
*An exception is found in Phase 3 where the model was altered to examine industry production, assuming the achievement of DOE price goals.
} 
Input to the model included estimates of size and breakeven prices for transition and residential markets.

The residential market was used as an index for determining the beginning of mass market penetration because the residential user can typically be expected to pay slightly more for electricity than commercial users and much more than industrial users.*

Althougli the restiential markct is an alequate mechanism for determining the relative impact of various incentivca, the coumercial/ industrial and utility markets must be considered in quantifying the full extent of an incentive's impact.

Results were projected for various combinations of the following :

- continuation of an agressive Federal research and development program

- achlevement of a technological breakthrough (identification, by the mid-1980's of photovoltaic collector technology that could achieve a FOB factory price of 10 to 30 cents per peak watt)

- immediate (1980-1990) or breakthrough-dependent incentives (incentives withhe1, until 1990 through 2000--after a breakthrough has occurred) including:

- direct price reductions (e.g., tax credits),

- keyed-to-breakeven subsidies (reduction in the price of a photovoltaic system in proportion to the difference hetween the market picicy of the systeil and the breakeven price of the application).

- Federal purchases

The effectiveness of each incentive was determined by its market impact and the leverage of Federal funds.

\footnotetext{
${ }^{\star}$ National Electrical Rate Book, Federal Power Commission, 1976.
} 
Market impact was measured by cumulative and annual collector sales and sales of systems in energy-saving mass markets. Leverage of Federal funds was determined by the Federal cost, collectors sold per Federal dollar invested, and systems sold in the mass market per Federal dollar.

This analysis resulted in the identification of the most promising of many broadly defined types of incentives. Conclusions which can be derived intuitively have been quantified and confirmed.

The findings based on this analysis represent only one step in a planning process to identify the "best" incentive. An investigation of delivery mechanisms and costs associated with promoting rapid achievement of a breakthrough and/or providing an immediate 50 percent keyed-to-breakeven subsidy would be a logical follow-up. The impact of commercial, industrial, utility and foreign markets must also be considered.

There are numerous mechanisms for each of the most promising types of incentives. Promoting a breakthrough, for example, could involve Federal laboratories, Federal grants to non-Federal sources, tax credits for private research, or guaranteed production support for breakthrough technology. A keyed-to-breakeven subsidy could be delivered as, for example, tax incentives for manufacturers or tax refunds to purchasers.

\section{MAJOR FINDINGS}

- DOE price goals of $50 \mathrm{c}$ per Watt peak by 1986 are probably achievable without incentives if a technological break-

$x i$ 
through occurs. Achievement of the goals would require markets that would be large enough to justify large-scale production of the breakthrough technology, once it is identified.

- A technological breakthrough by the 1980 s would have a greater impact than any reasonable program of Federal incentives offered in 1980-1990 or 1990-2000. This emphasizes the need to continue and possibly improve or expand the Federal $R$ and $D$ program, thus increasing the probability of a breakthrough.

- If a technological breakthrough occurs, immediate or breakthrough-dependent incentives would have similar impact and leverage.

- If a breakthrough does not occur, immediate incentives would increase the impact and leverage of Federal expenditures.

- A 50 percent keyed-to-breakeven subsidy appears to be the most promising incentive for assuring high impact and leverage, with or without a breakthrough. However,

- A firm identification of the best incentive option will require additional analys is of incentive delivery mechanisms and associated administrative costs. 


\subsection{INTRODUCTION}

Photovoltaic systems provide a clean, simple method for the conversion of sunlight into electrical energy. The systems are silent and require no complex machinery, heat engine cycle, or intermediate conversion to heat.

However, the existing photovoltaic industry is small--it presently consists of about 10 manufacturers and vendors of collectors or arrays.*

The current costs of photovoltaic systems are the greatest barrier to extensive market penetration and industry growth. The current capital cost of photovoltaic collectors ranges from $\$ 12$ to $\$ 30$ per peak watt for silicon flat plate arrays. The electricity they produce is 25 to 100 times more expensive than electricity generated by conventional energy sources. ${ }^{* *}$ As a result, current applications of photovoltaic systems are small-scale--i.e., generally less than one peak kilowatt--and most are located in remote areas where utility grid inter-ties would be very expensive. A total of approximately 700 peak kilowatts (kWp) were delivered in 1977.*

Federal action could be a.major factor in promoting the development of a commercially viable, competitive photovoltaic industry. In recognition of this potential, MITRE/Metrek has analyzed alternative

\footnotetext{
* Photovoltaic Incentives Option--Preliminary Report to Congress, the BDM Corporation, Sponsored by DOE, August 1978 .

** Based upon a 10 percent fixed charge rate, a 20 percent capacity factor for flat-plate photovoltaic collectors, and a balance-ofsystem price that is comparable to the collector price.
} 
Federal options to determine their relative merits in providing for adequate growth of the photovoltaic industry. The most promising of many broadly defined types of incentives have been identified. These findings may be used to help focus the detailed analysis of delivery mechanisms and costs that would be needed to identify "the best incentive."

Although quantitative methods have bcen used in Linis analysis, MITRE rccognizes that lhe numeric results are highly ocnsitive tu cost and market assumptions that are fraught with uncertainty. For this reason, the numeric results in this report are presented only as indices of relative merit. 


\subsection{SCOPE OF THE STUDY}

\subsection{Markets}

There are three potential-markets for photovoltaic systems: current markets, intermediate/transition markets, and energy-saving/ mass markets. The current market includes the relatively high-priced remote applications (such as microwave and radio repeaters, and cathodic protection equipment) which are now being sold by private industry.

Intermediate/transition markets include those applications that would require a sales price that is lower than current prices to be competitive against other available energy, sources. These applications, which may include, for example, irrigation and remote village power, generally have no economical access to electric grid power.

Energy-saving/mass markets are comprised of applications that would require sales prices that are competitive with grid-supplied energy generated with conventional fuels. Major uses could include systems for residential, commercial, and industrial buildings and utilities for central power generation.

This analysis focused on identifying options that would promote industry growth through the transition markets and either stimulate or initiate penetration of the mass markets. 


\subsection{Incentive Cases}

The following three types of incentive cases were analyzed. Possible mechanisms for administering each option are discussed in Appendix D:

- continuation of an agressive, Federally sponsored research and development (R\&D) program

- immodiatc incentivés cunstiscing of:

- direct price reductions of 10,20 , and 30 percent in the years 1980 tn $20 n n$

- keyed-to-breakeven subsidies of 25,50,75, and 100 percent in 1980 to 1990

- Federal purchases of 50-1000 MWp in the years 1981-1990

- Breakthrough-dependent incentives (offered if breakthrough technology is identified) consisting of:

- keyed-to-breakeven subsidies of $25,50,75$, and $10 n$ percent in the years 1990 to 2000

- Federal purchases of 50-1000 MWp in the years 1990 to 2000

The direct price reduction could be implemented as, for example, a consumer tax credit or producer subsidy. In this analysis, the incentive was applied to all photovoltaic saleo, regardless of the breakoven coste of application.

The keyed-to-breakeven subsidies would be applied only to applications where photovoltaic technology is not economically competitive. The subsidy would reduce the price of a photovoltaic system in proportion to the difference between the market price of the system and the breakeven price of the application. 
The Federal purchase incentive could increase industry production, thus reducing single-unit production costs through economiesof-scale. The purchase would not necessarily require that the photovoltaic application be economically competitive with other energy sources.

\subsection{Technology Development}

The impact of each incentive option was projected for both breakthrough and non-breakthrough technology development.

Breakthrough technology development has been defined as the near- to mid-term (mid-1980's) identification of photovoltaic collector technology that could achieve a FOB factory price of 20 cents per peak watt. This is consistent with the DOE goal of 10 cents to 30 cents per peak watt around the year 1990. It is assumed that the breakthrough will result from the development of low cost types of advanced collectors (e.g., thin films or compound cell concentrators) and/or advanced production processes (e.g. ribbon growth of silicon). The experience accumulated in the production of existing technology will not necessarily be applicable to the new cell types or production processes.

Non-breakthrough technology development has been defined as the evolutionary (gradual) reduction of collector price. This reduction is assumed to result from cumulative production experience and the gradual introduction of new technology. 


\section{0 METHODOLOGY}

The photovoltaic incentive analysis was performed in three phases :

- Phase 1 consisted of a preliminary screening to identify the incentive cases with the greatest potential impact and leverage of Federal funds

- Phase 2 consisted of a more detailed analysis of the three lases with the greatest potential

- Phase 3 consisted of an analysis to determine how alternative assumptions would affect the results from Phases 1 and 2 MITRE's photovoltaic market response model was used in each phase of the analysis. The model utilizes a market share function to estimate the fraction of a potential market that will be captured by the photovoltaic industry. Reductions in photovoltaic pricco result from cumulative production experience rather than price/time relationships.

In Phases 1 and 2, input to the model included estimates of sizo and breakeven prices for transition and residential markets.

The residential market was used as an index for determining the beginning of mass market penetration. This is becauoc the residull= tial user can typically be expected to pay slightly more for electricity than commercial users and much more than industrial users.*

\footnotetext{
*National Electrical Rate Book, Federal Power Commission, 1976.
} 
Although the residential market is adequate for determining the relative impact of various incentives, the commercial/industrial and utility markets must be considered in quantifying the full extent of an incentive's impact. The potential impact of these markets and foreign markets was estimated in Phase 3.

\subsection{Composition of Transition Markets}

There is a large degree of diversity and fragmentation among the various domestic transition markets. As a result, estimates of the transition market size and composition vary greatly.*

In this study, MITRE has adopted a modified version of the markets described by BDM.** Market sectors contained in the BDM estimates include:

$\begin{array}{lll}\text { agriculture } & \text { forestry } & \text { military } \\ \text { commerce and service } & \text { household/comsumer } & \text { mining } \\ \text { communication } & \text { industry } & \text { transportation } \\ \text { construction } & \text { leisure/recreation } & \text { utilities (auxiliaries) }\end{array}$

The size of the total transition market is summarized in

Table I. Appendix B gives a listing of the approximately 140 applications in this markel.

\subsection{Composition of Mass Markets}

The residential and commercial market estimates were derived from the SPURR*** data base. The total market potential was assumed

*BDM Corporation, Draft Final Report-Photovoltaic Power Systems

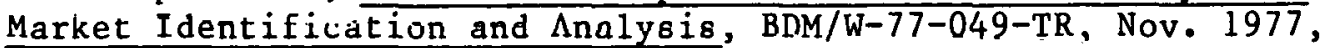
Vol. II.

Intertechnology Corp., Photovoltaic Power Systems Market Identi-

fication and Analysis, 1977.

SERI, Venture Analysis.

**BDM Op. cit.

wirsystem for Projecting Utilization of Renewable Resources. 
TABLE I

TRANSITION MARKET DATA AND SYSTEM PRICE

\begin{tabular}{|c|c|}
\hline $\begin{array}{c}\text { BREAK-EVEN } \\
\text { LIFE-CYCLE SYSTEM PRICE } \\
\text { (1986 prices in } 1975 \text { dollars } \\
\text { per Watt peak) }\end{array}$ & $\begin{array}{c}\text { POTENTIAL MARKET SIZE } \\
\text { MW PEAK/YR* }\end{array}$ \\
\hline $\begin{array}{l}>20 \\
10-20 \\
5-9.9 \\
1-4 \cdot 9 \\
1 \text { OR LEES }\end{array}$ & $\begin{array}{r}.7 \\
5 \\
5 \\
3.30 \\
6,050 \\
6,393\end{array}$ \\
\hline
\end{tabular}

* This is a composite--not all applications are available in all years of the market penetration analysis.

(SOURCE: BDM/MITRE) 
to encompass all new building construction. However, only a fraction of all new buildings was estimated to be suitable for solar (including photovoltaic) systems. This suitability fraction was assumed to increase with time as a result of, for example, increased solar awareness on the part of construction contractors and consumers. Estimates of the residential and commercial market potential and suitability fractions assumed in this analysis are summarized in Table II. Estimates of the potential markets for central utility systems were based upon the National Energy Plan scenario for electrical energy demand through the year 2000. For photovoltaic systems, the potential market penetration was limited to supplying 10 percent of this demand.*

Photovoltaic central utility systems may provide energy at a capacity factor of about 25 percent for fuel savers (photovoltaic systems with no dedicated energy storage) in the southwestern United States. ${ }^{* *}$ Based upon this and the demand scenario stated above, Table III shows total potential central utility markets through 2000 .

\subsection{Market Response}

Market allocation among competing conventional and solar technologies is determined by first computing a Figure of Merit (FOM) *EPRI states 5 percent as a reasonable national value, with a range approaching 20 percent in some regions of the U.S. See Requirements Assessment of Photovoltaic Power Plants in Electric Utility Systems, Electric Power Research Institute, EPRI ER-685-SY, Vols. 1-3, June, 1978.

**Systems Description and Engineering Costs for Solar-Related Technologies--Photovoltaic Central Power Systems, MITRE Corp., MTR-7485, Vol. VIII, June, 1977. 
TABLE II

MARKET POTENTIAL AND SUITABILITY OF RESIDENTIAL AND

COMMERCIAL BUILDINGS--NEW CONSTRUCTION

\begin{tabular}{|c|c|c|c|}
\hline BUILŨING 'IYYE & YEARS & $\begin{array}{c}\text { TOTAL } \\
\text { MARKET POTENTIAL: } \\
\text { NEW CONSTRUCTION } \\
\text { (thousands of bldgs/yr) }\end{array}$ & $\begin{array}{l}\text { SUITABILITY } \\
\text { FRACTION FOR } \\
\text { SOLAR ENERCY } \\
\text { SYSTEMS }\end{array}$ \\
\hline $\begin{array}{l}1-\& 2-\text { Family } \\
\text { Residences } \\
\text { (sunbelt) }\end{array}$ & $\begin{array}{c}1979 \\
1980 \\
1981-1985 \\
1986-1990 \\
1991-1995 \\
1996-2000\end{array}$ & $\begin{array}{l}920 \\
920 \\
920 \\
920 \\
950 \\
980\end{array}$ & $\begin{array}{l}0.05 \\
0.2 \\
0.5 \\
0.6 \\
0.7 \\
0.8\end{array}$ \\
\hline $\begin{array}{l}1-\& 2-\text { Family } \\
\text { Residences } \\
\text { (non-sunbelt) }\end{array}$ & $\begin{array}{c}1979 \\
1980 \\
1981-1985 \\
1986-1990 \\
1991-1995 \\
1996-2000\end{array}$ & $\begin{array}{l}122 \\
1,220 \\
1,220 \\
1,220 \\
1,260 \\
1,310\end{array}$ & $\begin{array}{l}0.05 \\
0.2 \\
0.5 \\
0.6 \\
0.7 \\
0.8\end{array}$ \\
\hline $\begin{array}{r}\text { Commercial } \\
\text { (sunbelt) }\end{array}$ & $\begin{array}{l}1983-1985 \\
1986-1990 \\
1991-1995 \\
1996-2000\end{array}$ & $\begin{array}{l}113 \\
113 \\
120 \\
127\end{array}$ & $\begin{array}{l}0.6 \\
0.7 \\
0.8 \\
0.8\end{array}$ \\
\hline $\begin{array}{l}\text { Commercial } \\
(\text { non=ounbclt })\end{array}$ & $\begin{array}{l}1983-1985 \\
1906-1990 \\
1991-1995 \\
1996-2000\end{array}$ & $\begin{array}{l}150 \\
150 \\
161 \\
170\end{array}$ & $\begin{array}{l}0.6 \\
0.7 \\
0.8 \\
0.8\end{array}$ \\
\hline
\end{tabular}


TABLE III

POTENTIAL PHOTOVOLTAIC CENTRAL UTILITY MARKET

\begin{tabular}{ccc}
\hline YEAR & $\begin{array}{c}\text { TOTAL U.S. DEMAND } \\
\text { FOR ELECTRIC ENERGY } \\
(\text { terawatt-hours/yr*) }\end{array}$ & $\begin{array}{c}\text { POTENTIAL PHOTOVOLTAIC } \\
\text { CENTRAL SYSTEM MARKETS } \\
\text { (in MWp of collectors/yr at } \\
10 \% \text { penetration of total demand) }\end{array}$ \\
\hline 1990 & 11.8 & 5630. \\
$1991-2000$ & 14.6 & 6970. \\
\hline
\end{tabular}

* One Terawatt-hour equals $10^{9} \mathrm{KWH}$. 
which represents the decision maker's risk-free preference for the solar technology. Then, an appropriate share of the market is inferred for the new technology as a function of time.

Early in the life of a new product, sales will increase as the product is introduced to the marketplace. Sales may occur even if the new product is not economically competitive with the product or products already serving the market, Ultimately, ecunumic criceria wil1. prednminate and non=oconomioally viable products will disappear from the market. Products which are economically competitive will remain, eventually gaining a substantial share of the market. In this analysis, the dynamics of increasing market acceptance and/or product failure are simulated by a substitution model similar to the "logit" or "S-shaped" curve presented by Fisher and Pry.* This model allows explicit specification of the value of the new technology relative to its conventional competitor by means of the FOM. Figure 1 shows the model plotted parametrically for various constant values of FOM.

Table IV shows the FOM used in this analysis. The FOM for residential markets was derived from a study which determined the attitudes of prospective home buyers toward solar energy.**

\footnotetext{
*Fisher, J. C. and Pry, R. H., "A Simple Substitution Model of Technological Change," Technological Forecasting and Social Change, Vol. 3, 1971, pp 75-88.

"Scott, Jerome E., Consumer Demand Analysis of Solar Heating and

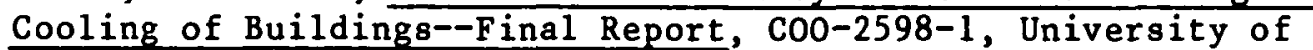
Delaware, 1976.
} 


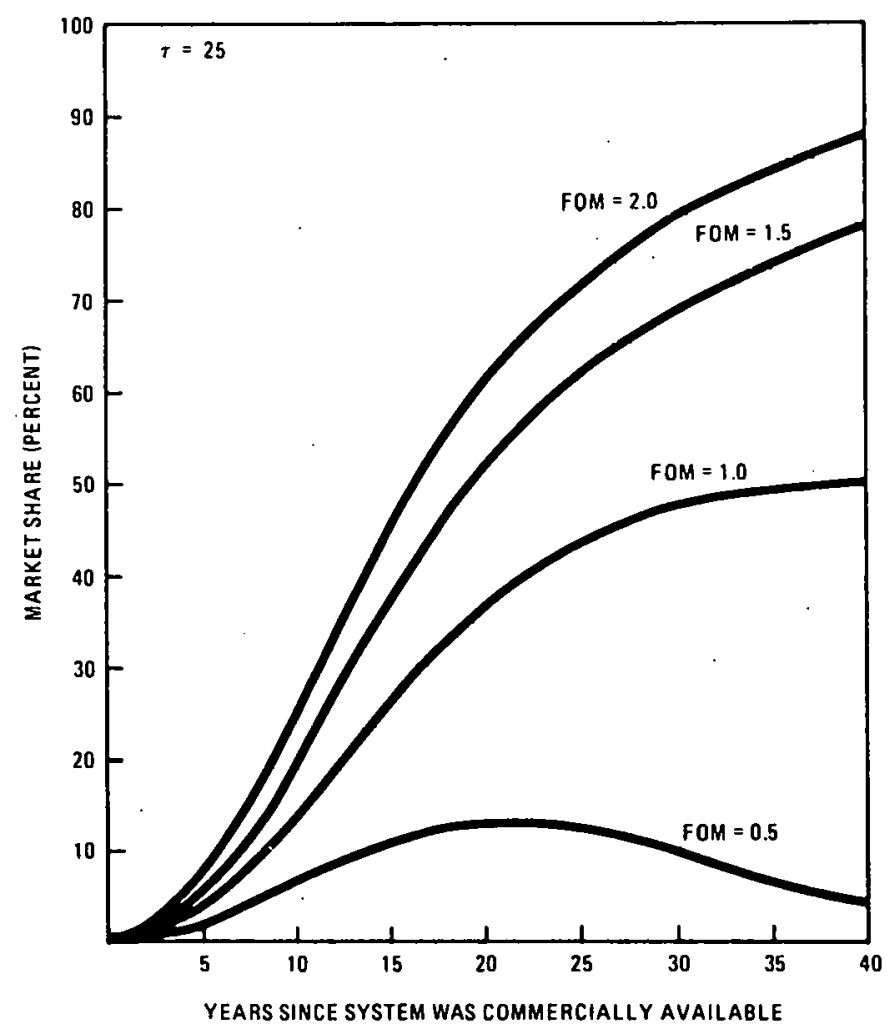

Source: A System for Projecting the Utilization of Renewable Resources--SPURR Merhodology, The MITRE Corporation, MTR-7570, September, 1977.

FIGURE 1

METREK MARKET SHARE

FUNCTION 
TABLE IV

FIGURE OF MERIT BY MARKET SECTOR

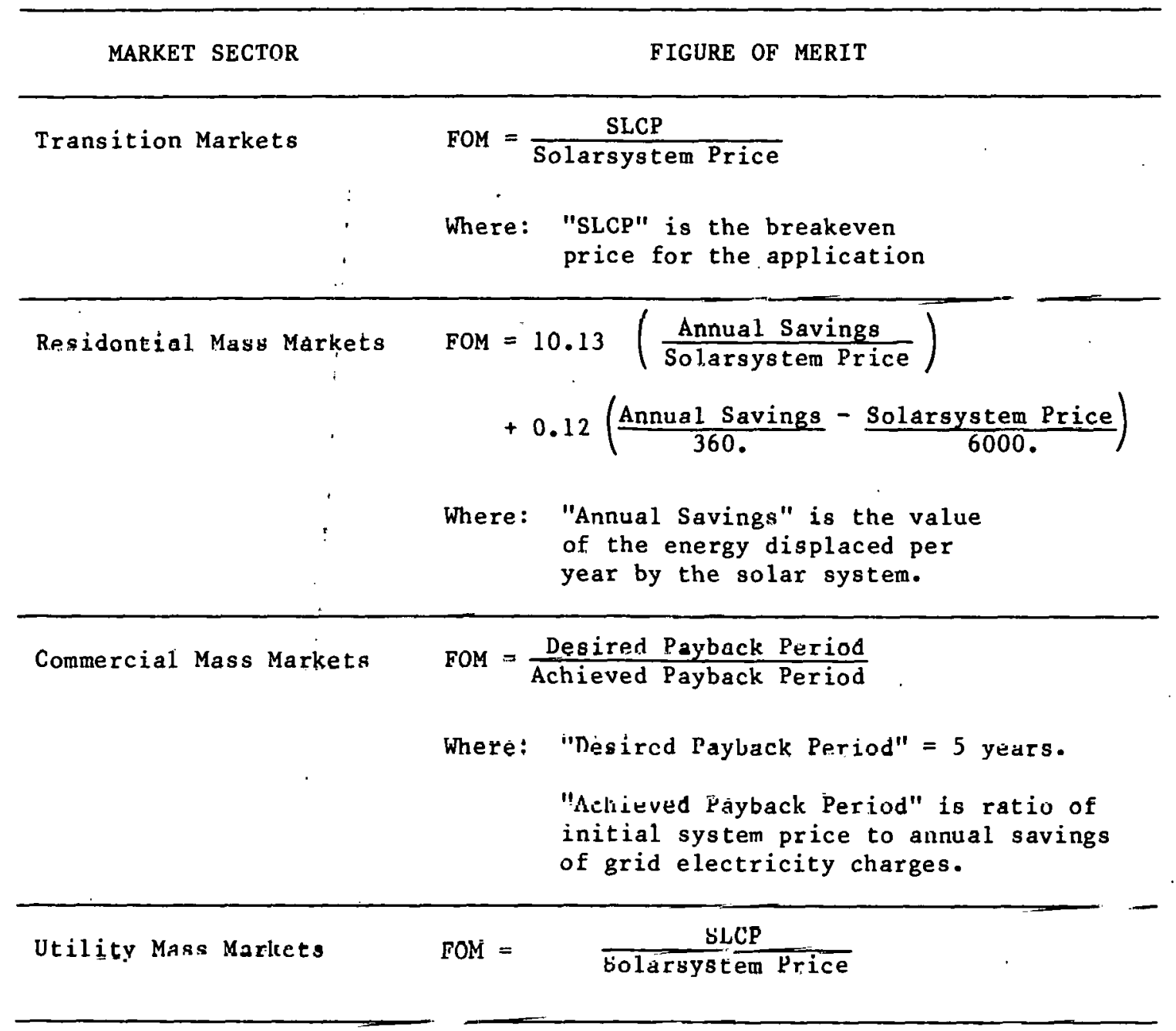


Transition and utility market Figures of Merit consisted of the ratio of breakeven price for each application to the current price of a photovoltaic system. Commercial applications employed a Figure of Merit consisting of the ratio of a desired payback period to a payback period which would be achieved by the photovoltaic system purchased at the current price.

\subsection{Photovoltaic System Assumptions}

Photovoltaic systems include collectors and the remaining portions of the systems which are referred to as the Balance of System (BOS). Figure 2 shows the various components and options for photovoltaic systems.

\subsection{System Size}

System sizes for transition market systems were determined by $\mathrm{BDM}^{*}$ and range from less than a watt through $40 \mathrm{MWp}$. These are listed in Appendix B.

Residential systems are all sized with $3.4 \mathrm{KWp}$ (rated) of collector. This is consistent with the residential photovoltaic system defined for the SERI Photovoltaic Venture Analysis.**

Commercial systems range in size from $50 \mathrm{kWp}$ through $500 \mathrm{kWp}$. The variation occurs in time with smaller system applications appearing initially and the larger systems applications becoming available as the technology evolves through the year 2000 .

\footnotetext{
${ }^{*}$ BDM, Op. Cit.

** Solar Energy Research Institute, Final Report--Photovoltaic Venture Analysis, SERI/TR-52-040, July 1978, Vols. I-III.
} 


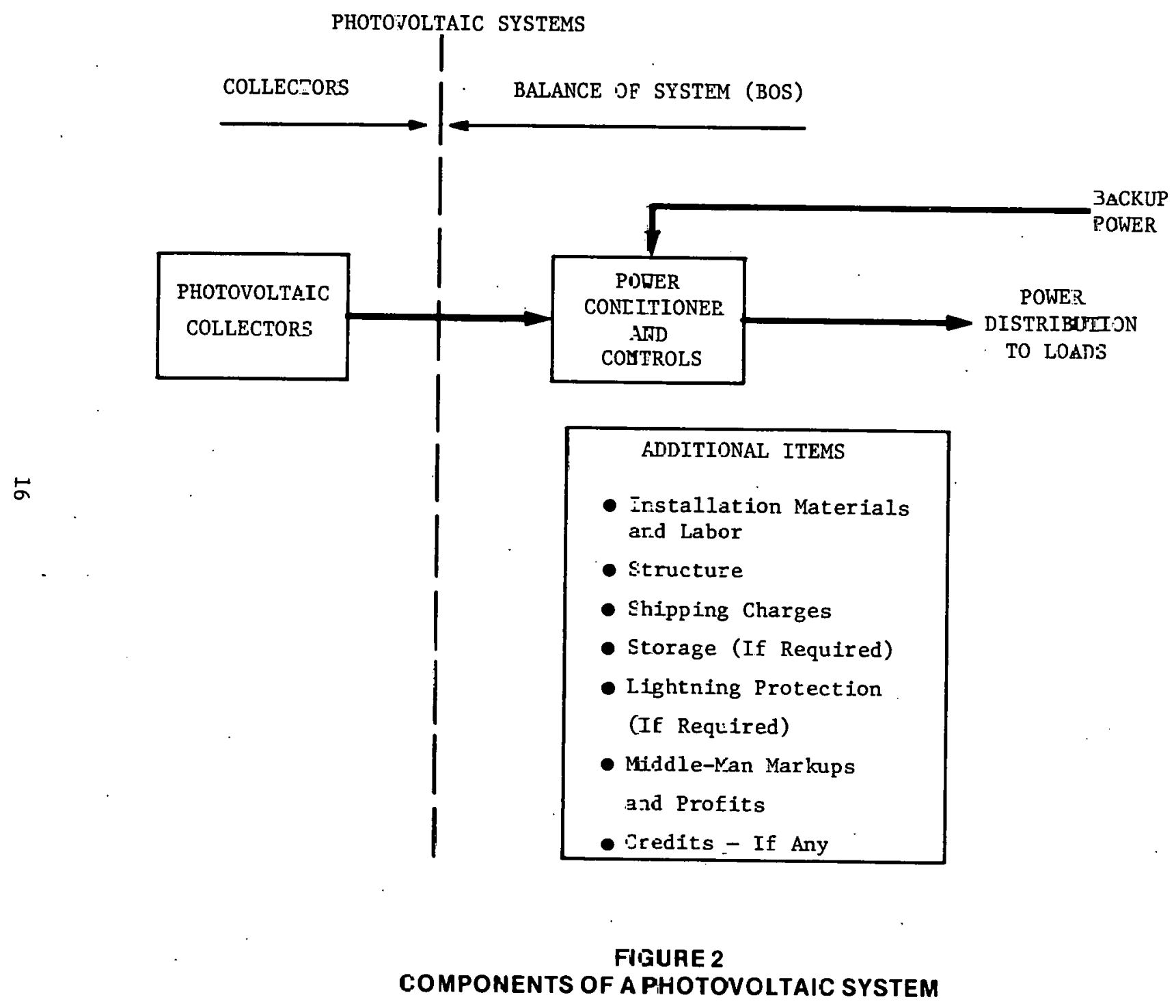


Utility systems range in size from $10 \mathrm{MWp}$ through $100 \mathrm{MWp}$. Again, the larger applications become available at the end of the 1979-2000 time frame.

\subsection{System Price}

In this analysis, the price of the photovoltaic system is taken as the sum of collector and BOS prices. Installation, structure, shipping, markups and credits are assumed to be contained in the BOS prices.

Prices (in constant year dollars) for collectors and BOS are assumed to reduce independent of each other, in response to the industry's cumulative production experience. Collector prices reduce more rapidly because BOS technology is assumed to be more conventional or better established.

Throughout this report, system, collector and BOS prices are given in terms of rated, peak collector power in constant 1975 dollars.

\subsection{Collector Price}

Industry response, or reduction in photovoltaic collector price, is assumed to result from cumulative production experience.* The modeling assumptions used in this analysis are summarized on Figures 3 through 6 .

Figures 3 and 4 show the market responses for evolutionary (nonbreakthrough) technology development.

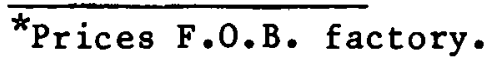




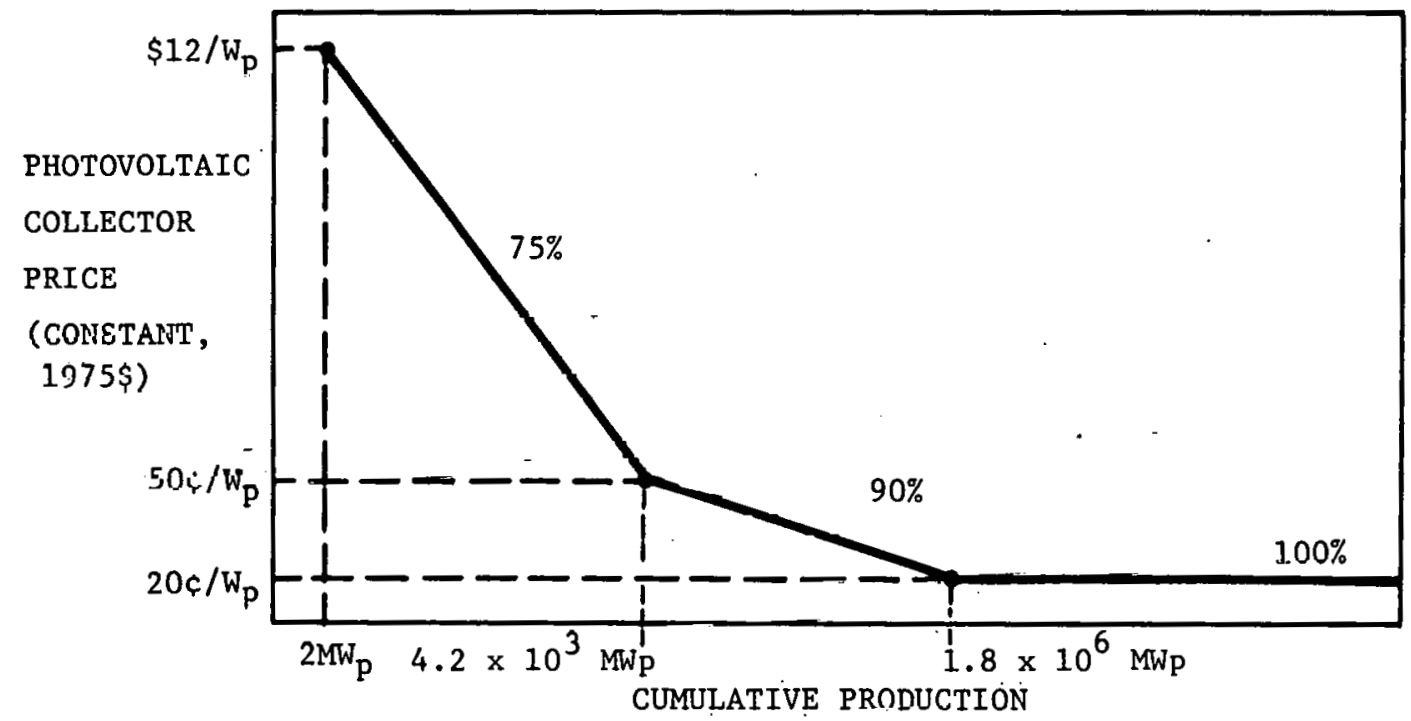

FIGURE 3

NO TECHNOLOGY BREAKTHROUGH, AGGRESSIVE FEDERAL R\&D PROGRAM

(PHASE 1 ANALYSIS CASES 2A AND B)

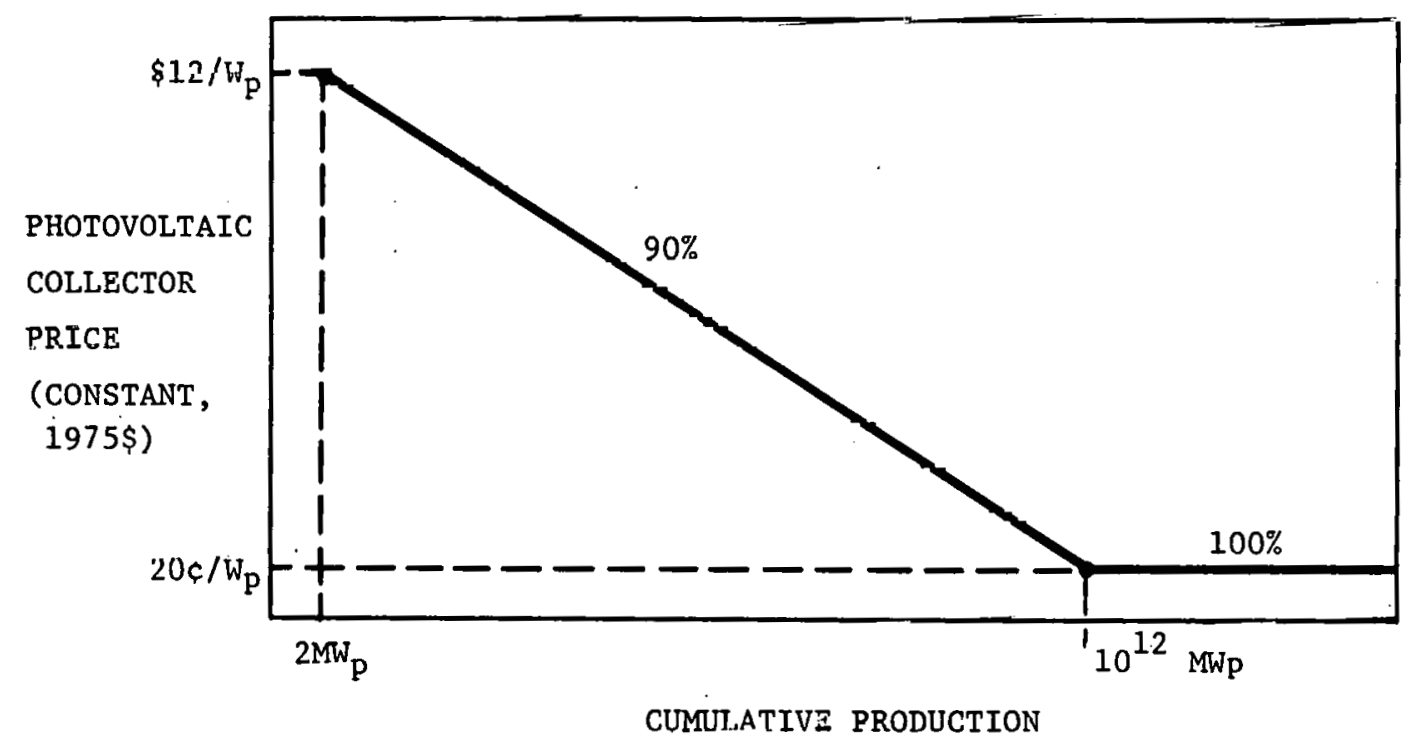

FIGURE 4

NO TECHNOLOGY BREAKTHROUGH, NO FEDERAL R\&D PROGRAM (PHASE 1 ANALYSIS CASES 4A AND B) 


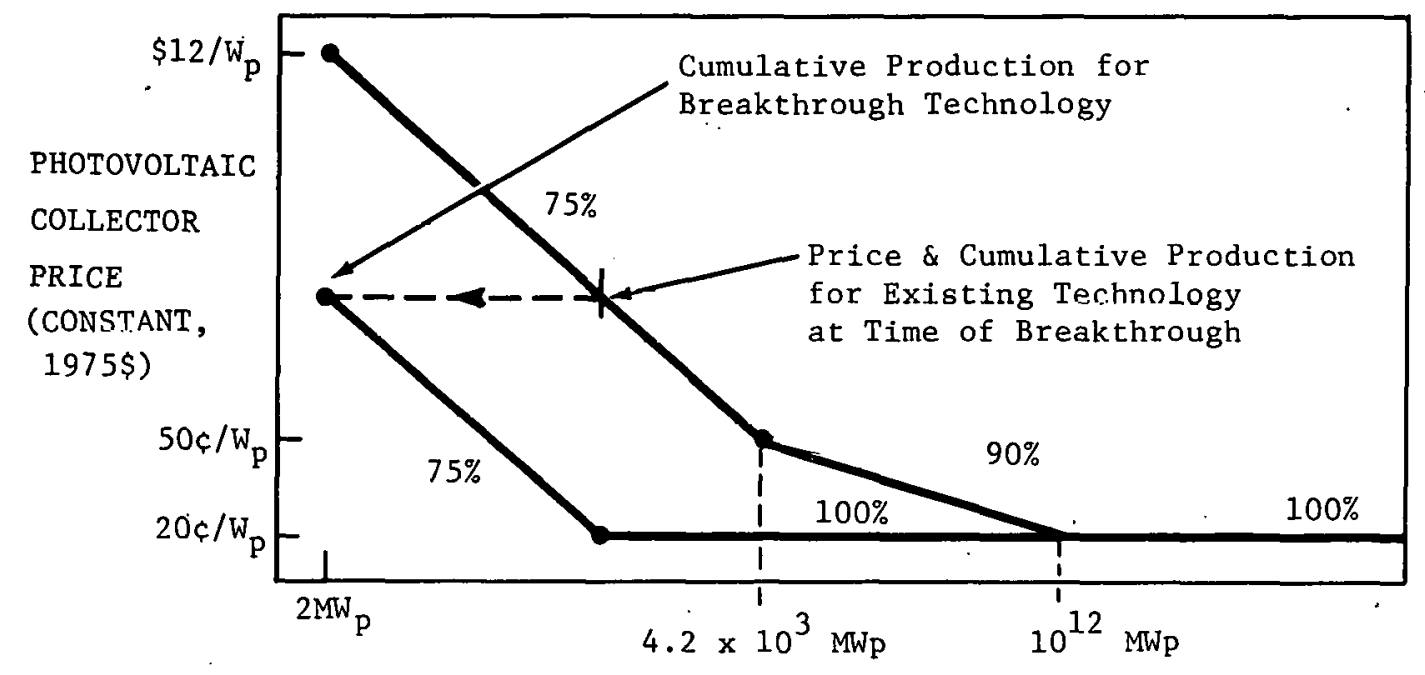

FIGURE 5

TECHNOLOGY BREAKTHROUGH, AGGRESSIVE FEDERAL R\&D (PHASE 1 ANALYSIS CASES 1 A, B AND C)

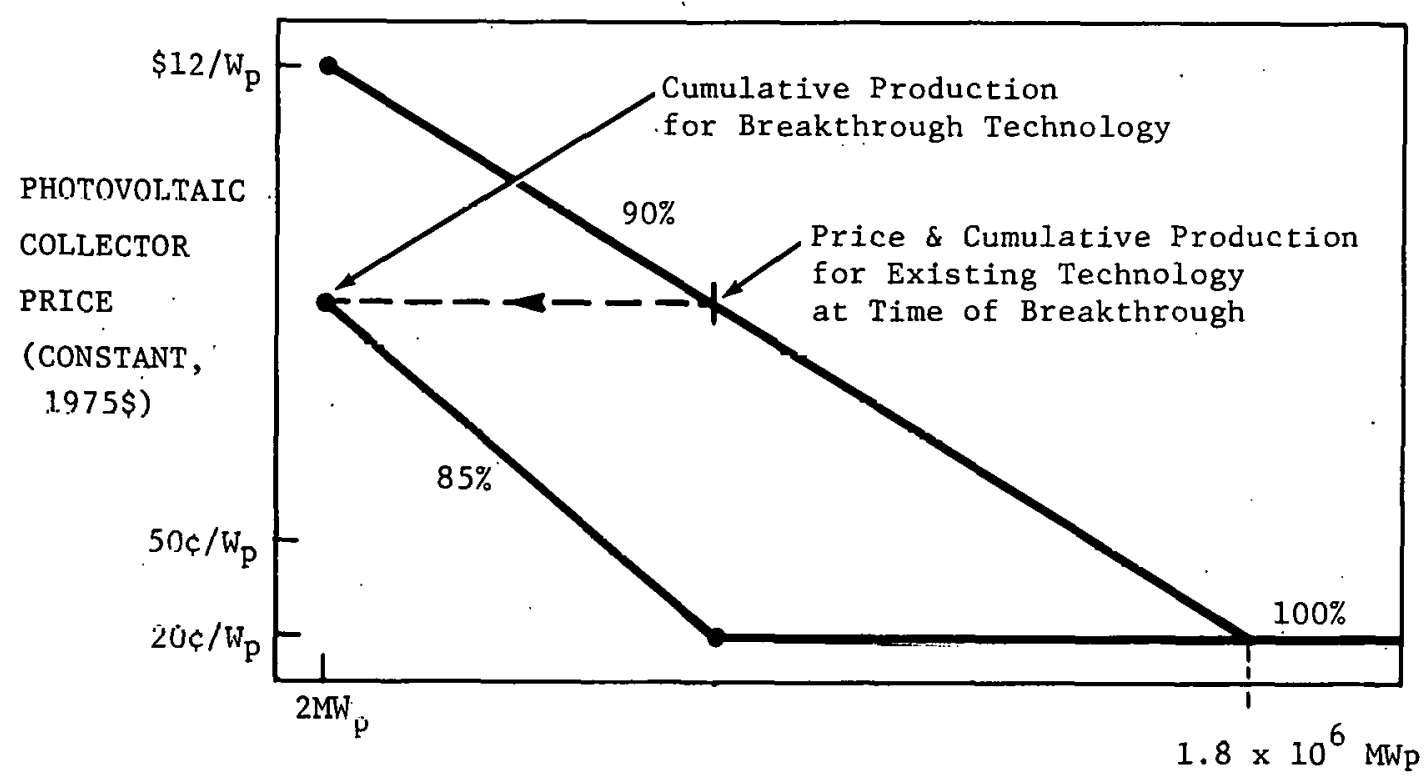

FIGURE 6

TECHNOLOGY BREAKTHROUGH, NO FEDERAL R\&D PROGRAM

(PHASE 1 ANALYSIS CASES 3A, B AND C) 
As shown in Figure 3, a rapid downward price trend for photovoltaic collectors was assumed to result from an aggressive, Federal R and D program. This Federal program would support development of both existing and new technology.

The rapid downward price trend is represented by a 75 percent experience curve slope through a price level of 50 cents per peak watt, ${ }^{\star}$ At $5 n$ cents, it is assumed that new techiulugy is required to serve the warket, Below 50 cents, the experience curve slope changes to 90 percent and price reductions continue to 20 cents per peak watt (assumed to be the ultimate price for new technology).** There is greater uncertainty in predicting the experience curves for low-cost technology whose characteristics are not yet known. This uncertainty about the technology and the rapidity with which it can be brought to its ultimate price is reflected in the 90 percent slope.

In Figure 4, the 90 percent slope reflects the assumption that, without an aggressive Federal $R$ and $D$ program, reduction in prices and growth in experience would be slow.

Figures 5 and 6 show the impacts assumed for a technology breakthrough. It is assumed that new "breakthrough" technology will differ substantially from existing technology*** and that the

\footnotetext{
${ }^{*}$ Prices F.0.B. factory.

** This is consistent with Federal program goals of $10-30$ cents per peak watt.

***As different, say, as Cd-S photovoltaic cells deposited on glass by spray techniques are from current Czochralski silicon cells fabricated by largely manual techniques.
} 
experience accumulated in production of existing technology is not necessarily applicable to the new technology. The new technology will enter the market at current prices and will share the market until low market price effectively drives out existing technology. This is modeled as an average 50 percent market share from the time of new technology introduction to the time at which market price falls below 50 cents per peak watt.

With an aggressive Federal program supporting technology development (Figure 5), breakthrough technology is assumed to decrease in price at a 75 percent rate to 20 cents per watt. Without the Federal program (Figure 6), the price decline is assumed to be slower.

In all cases, the initial conditions for collector price and cumulative production experience are taken as $\$ 12 / \mathrm{Wp}$ and $2 \mathrm{MWp}$, respectively.

\subsection{Balance of System Prices}

The Balance of System (BOS) prices that were used in this analysis are shown on Tables $\mathrm{V}$ and $\mathrm{VI}$.

A single estimate of BOS prices derived from 13 applications was assumed for the transition markets. Initial BOS costs of $\$ 15 / \mathrm{Wp}$. were allowed to reach an ultimate level of $\$ 0.80 / \mathrm{Wp}$. This reflects improvements in BOS design and a trend in the transition market from initial installation of small systems in small quantities, to numerous larger systems. 
TABLE V

BALANCE OF SYSTEMS PRICE ASSUMPTIONS

\begin{tabular}{|c|c|c|}
\hline MARKET SECTOR & BOS PRICE* & REMARKS \\
\hline Transition & $\begin{array}{l}\$ 15.04 / \mathrm{Wp} \text { decreasing with } \\
\text { experience at an } 80 \% \text { slope } \\
\text { to } \$ 0.80 / \mathrm{Wp} \text {. }\end{array}$ & $\begin{array}{l}\text { See TableVI for a break-down } \\
\text { of Trangition BoS priod. }\end{array}$ \\
\hline Residénlial & $\begin{array}{l}\$ 0.91 / \mathrm{Wp} \text { üp to } 1000 \text { systems } \\
\text { decreasing with experience } \\
\text { to } \$ 0.59 / \mathrm{Wp} \text { at } 10,000 \text { sys- } \\
\text { tems (approximately, an } 80 \% \\
\text { slope). }\end{array}$ & $\begin{array}{l}\text { Comprised of } \$ 0.32 / W p \text {, fixed, } \\
\text { plus power conditioner price } \\
\text { of } \$ 0.59 / \text { Wp reducing to } \$ 0.27 / \\
\text { Wp. Source: SERI Venture } \\
\text { Analysis--Final Report, Vol. 1, } \\
\text { pg. } 126, \text { July, } 1978 . \text { Prices } \\
\text { used are averages of ranges } \\
\text { presented. }\end{array}$ \\
\hline $\begin{array}{l}\text { Commercial/ } \\
\text { Industrial }\end{array}$ & $\begin{array}{l}\text { \$0.93/Wp up to } 1000 \text { systems } \\
\text { decreasing with experience } \\
\text { to } \$ 0.35 / W p \text { at approximately } \\
\text { an } 80 \% \text { slope. }\end{array}$ & $\begin{array}{l}\text { Ultimate price of } \$ 0.35 / W p \text { from } \\
\text { the Long Term Demand Estimation, } \\
\text { MIT Energy Laboratory, for the } \\
\text { SERI Photovoltaic Venture Analy- } \\
\text { sis. Initial prire of } \$ 0.93 / W p \\
\text { is the average of the range of } \\
1986 \text { BOS prices expressed in } \\
\text { Volume I (Table 26) of the SERI } \\
\text { Venture Analysis. }\end{array}$ \\
\hline Utility & $\$ 0.38 / W p$ & $\begin{array}{l}\text { Snurce: } \frac{\text { SERI Vonture Analysis, }}{\text { Vol. I, Tahle 2G. }}\end{array}$ \\
\hline
\end{tabular}

*Prices are in terms of 1975 dollars per rated, peak collector power. 
TABLE VI

ASSUMPTIONS: BALANCE OF SYSTEMS FOR TRANSITION MARKETS

\begin{tabular}{lc}
\hline \multicolumn{1}{c}{ ITEM } & $\begin{array}{c}\text { TRANSITION } \\
\text { PRICE }(\$ / \mathrm{Wp})^{*}\end{array}$ \\
\hline Balance of Systems (BOS) & \\
Battery Storage & 3.00 \\
Power Conditioning & 0.82 \\
Structure & 1.59 \\
Installation & 6.34 \\
O\&M & 2.13 \\
Replacement & 1.16 \\
TOTAL BOS & 15.04 \\
\hline
\end{tabular}

*Average prices for 13 selected domestic applications based upon 1978 technology. Prices are expressed in 1975 dollars. From the Solar Energy Research Institute, Photovoltaic Venture Analysis-Interim Report, SERI-33, Vo1. II, Appendix B, May, 1978. 


\subsection{General Economic Assumptions}

Table VII shows the general economic parameters assumed for this analysis. The table shows a moderate general inflation rate of 6 percent with all conventionally generated electrical energy prices escalating 2 percent faster regardless of source.

A 10 percent general discount rate was originally intended ro be a comprọnise amnng residential mortgage rates, commercial/ industrial interest rates and plectric utility average cost of money. With recent trends in home mortgage rates, this may be slightly low--a 12 to 14 percent rate might be more appropriate.

The financial life of a photovoltaic system was taken as 20 years. This reflects the estimates made by DOE of the design life of the photovoltaic system although the actual physical life could be well in excess of this period.

Simple payback is a criterion frequently used in commercial and industrial ventures. Although payback periods of 12-24 months are common criteria, for financial investments, a large capital invegtment with a long lifo could warrant a five year payback period. This may be particularly 80 in the case of solar technology since there is a good deal of uncertainty about the price of non-solar alternatives in the future. 
TABLE VII

ECONOMIC PARAMETERS

\begin{tabular}{|c|c|c|}
\hline PARAMETER & VALUE & REMARKS \\
\hline $\begin{array}{l}\text { Conventional Energy Source } \\
\text { Price Escalation Rate }\end{array}$ & $8 \% /$ yr. & As sumed \\
\hline General Inflation Rate & $6 \% / \mathrm{yr}$ & As sumed \\
\hline General Discount Rate & $10 \% / \mathrm{yr}$ & $\begin{array}{l}\text { Assumed. May be slightly } \\
\text { low. }\end{array}$ \\
\hline $\begin{array}{l}\text { Photovoltaic System } \\
\text { Financial Life }\end{array}$ & $20 \mathrm{yr}$ & $\begin{array}{l}\text { Federal Program goal for } \\
\text { residential and commercial } \\
\text { systems. }\end{array}$ \\
\hline Commercial Payback Period & $5 \mathrm{yr}$. & $\begin{array}{l}\text { Derived from Technical } \\
\text { and Economical Feasibility } \\
\text { of Solar Augmented Process } \\
\text { Steam Generation, Thermo } \\
\text { Electron Corp., } 1976 .\end{array}$ \\
\hline
\end{tabular}




\subsection{PHASE 1 ANALYSIS}

\subsection{Approach}

Phase 1 of the analysis consisted of a preliminary screening of 10 incentive cases. The incentive cases and the options they include are described in Figure 7.

The effectiveness of each incentive was determined by its market impact and leverage of Federal fundo.

Market impact was measured by cumulálive and annual collector sales, and sales of systems in energy saving mass markets. Leverage of Federal funds was determined by Federal cost, collectors sold per Federal dollar invested, and residential systems sold per Federal dollar.

These effectiveness criteria were chosen because they are believed by MITRE to be of similar importance.

All of the options in this analysis were ranked for each effectiveness criterion. A value of "good" was assigned to approximately one-third of the options that had the highest numerical results, "moderate" for results in the middle range, and "poor" for approximately one-third of the options with the lowest results. Case values for each criteria were established by the ayorage rating of the options within the case. This method was chosen to minimize the dependence upon actual numbers generated in the analysis.*

\footnotetext{
*An alternative method would have been to establish thresholds for success based on definitions of healthy industry growth. Numerical results produced in the analysis would be compared to the established thresholds. The "good," "moderate" or "poor" value of each option would then be critically dependent upon market assumptions used in the model and upon definitions of an economically viable industry.
} 


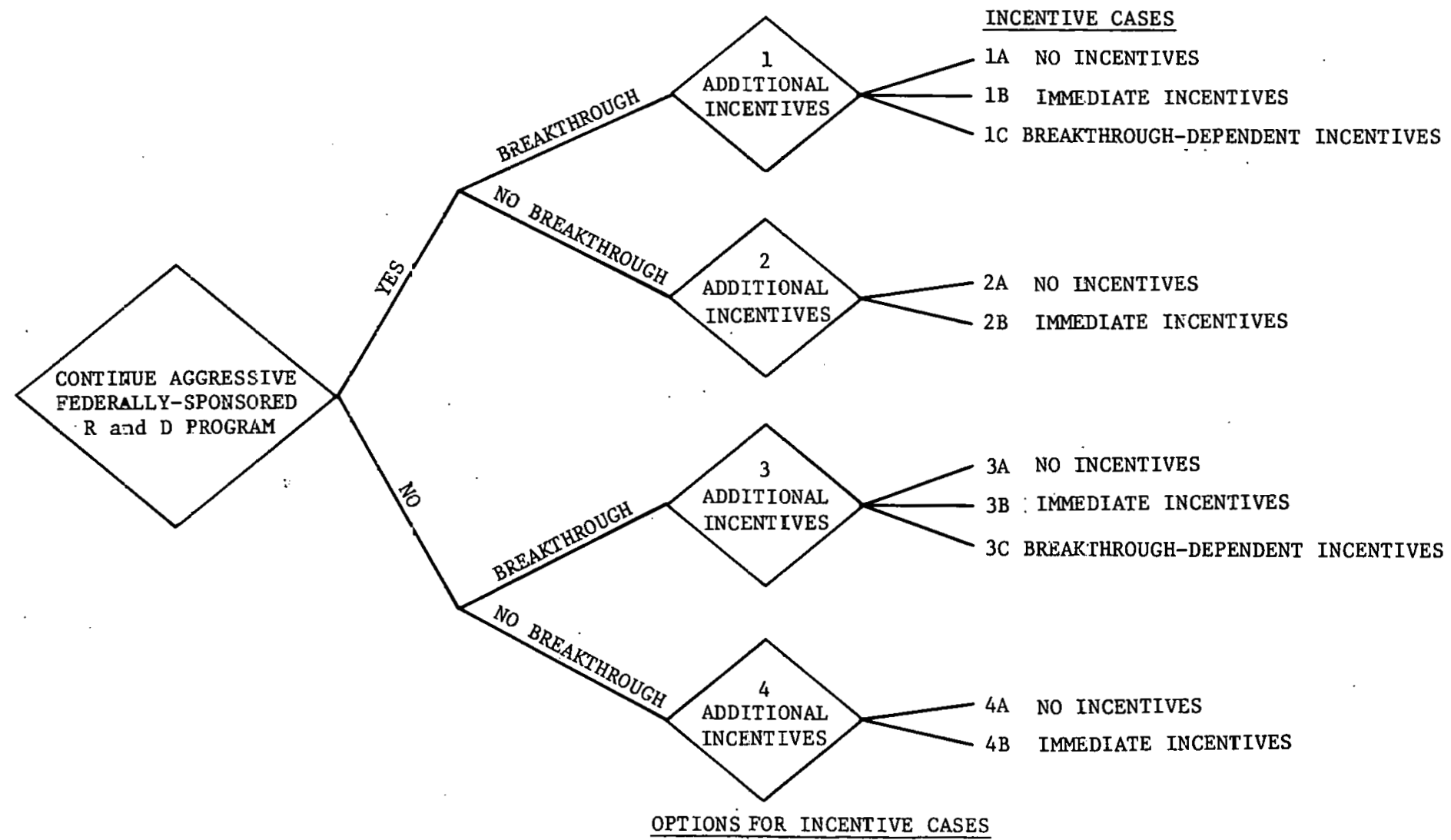

Immediate Incentives Include:

- Direct price reductions of 10,20 and 30\% (1980-2000)

- Breakeven subsidies of 25, 50, 75 and 100\% (1980-1990)

- Federal purchases of 50 to $1000 \mathrm{Mhp}$ (1981-1990)
Breakthrough-Dependent Incentives Include:

- Breakeven subsidies of 25, 50,75 and 100\% (1990-2000)

- Federal purchases of 50 to 1000 MWp (1990-2000)

FIGURE 7

PHASE 1 INCENTIVE CASES AND OPTIONS 


\subsection{Results and Conclusions}

The results of the Phase 1 analysis are summarized in Table

VIII. (The original data are contained in Appendix A.) The following conclusions may be derived from these results:

1. An aggressive, Federally-sponsored research and development program should be continued. Incentives conld not compensate tor the detrimental effect of withdrawing the Foderally-oponsoled $R$ aud $D$ program.

- Each of the cases with Federally-sponsored $R$ and $D$ (Cases 1A, 1B, 1C and 2B) had greater impact than the cayes without Federal $R$ and $D$ (Cases 3 and 4 ).

- Huge Federal incentives and expense would be required to achieve results comparable to those of an aggressive $R$ and $D$ program. For instance, the achievement of $a$ moderate residential market penetration in the year 2000, with a Federal $R$ and $D$ program, would require greater than $\$ 21$ billion through an immediate or breakthroughdependent 100 percent subsidy (see Appendix A, Cases 3B and $3 \mathrm{C}$ ).

For these reasons, cases without an aggressive, Federally-sponsored

$R$ and $D$ program (Cases 3 and 4 ) werc exeluded frum furcher analysis.

2. A technology breakthrough without additional incentives would have a greater impact than immediate incentives without a breakthrough. This emphasizes the need to continue (and possibly improve or eypand) the Fcdcral $R$ and $D$ prom gram to increase the probahility of a breakthrough.

- A breakthrough with no incentives (Case 1A) has greater impact and leverage than no breakthrough with immediate inoentives (Oase 2B). This result is based on the assumption that pricc is a major barricr to markel penetration and that if technology can achieve a competitive price, no further incentive is needed to stimulate market penetration.

3. If a breakthrough occurs, immediate or breakthroughdependent incentives provide only a slight increase in impact and leverage. 
TABLE VIII

SIMMARY OF PHASE 1 ANALYSIS

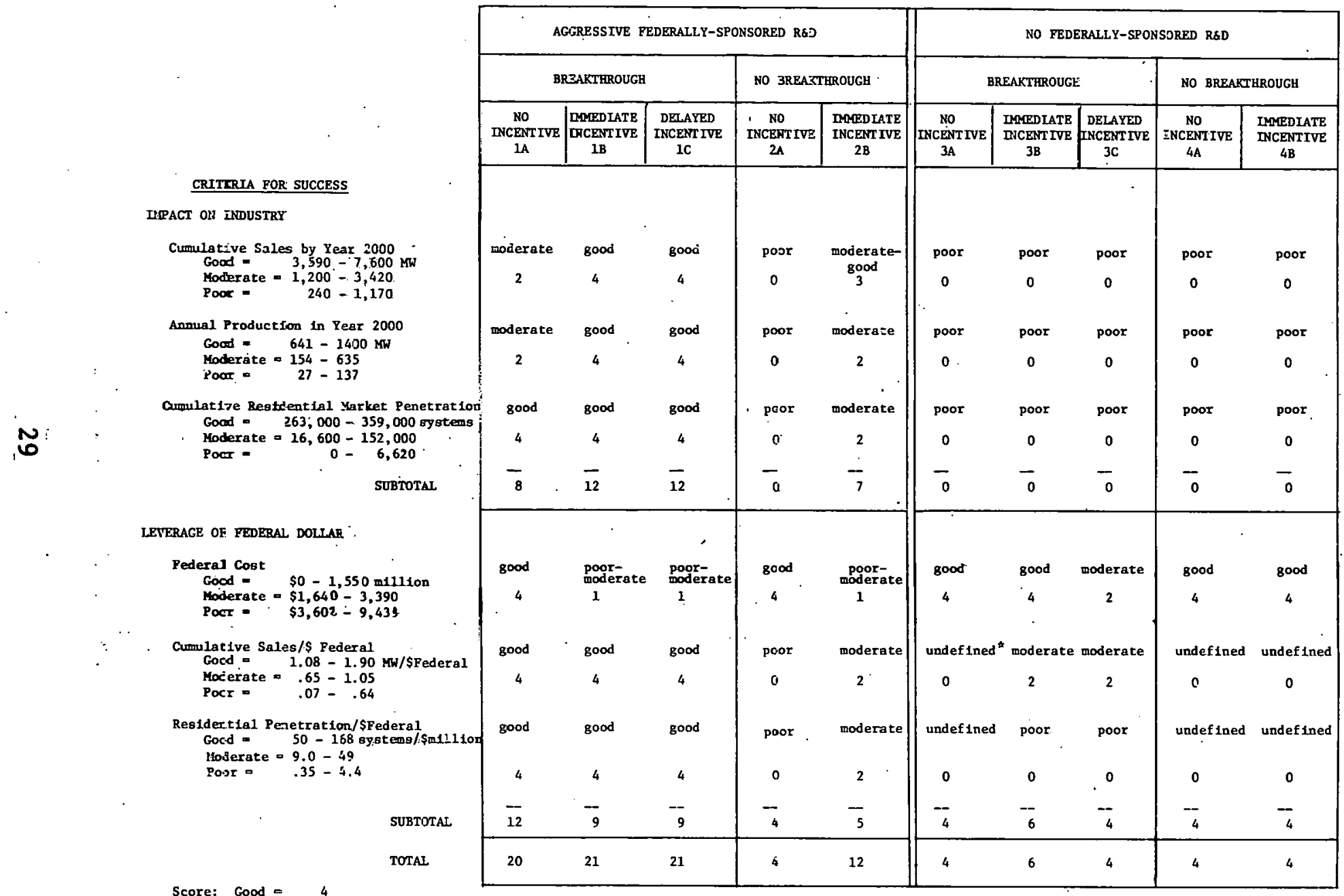

$\begin{array}{ll}\text { Cood }= & 4 \\ \text { Moderate }= & 2 \\ \text { Poor }= & 0\end{array}$

$\star_{\text {denouinator }}=0$ 
- Immediate incentives with a breakthrough (Case 1B) and breakthrough-dependent incentives (Case 1C) have higher impact and lower leverage than a breakthrough without incentives (Case 1A). The total impact and leverage for Cases $1 B$ or 1C is only slightly larger than the total for 1A. As in the preceding conclusion, these results are based on the assumption that price is the major barrier to market penetration. Without a breakthrough, extremely expensive incentives would be required to achieve the large price reduction that is assumed to result from a technology breakthrough.

4. If a breakthrough does nor occurr, fmimediate incentives would increase the impact and leverage of Federal funds.

- Immediate incentives (Case 2B) scored higher than no incentives (Case 2A) for all criteria except. Federal cost.

In summary, the cases with the greatest potential impact and leverage are:

I 1A--breakthrough without incentives

- 1B--immediate incentives with a breakthrough

- 1C--breakthrough followed by incentives

- 2B--immediate incentives; no breakthrough 


\subsection{PHASE 2 ANALYSIS}

\subsection{Approach}

The same 6 criteria for success that were used in Phase 1 of this analysis were used in Phase 2 to establish a relative ranking of options for the breakthrough cases (1A, no incentives, 1B, immediate incentives and $1 \mathrm{C}$, breakthrough-dependent incentives) and for the non-breakthrough case (2B, immediate incentives).

\subsection{Results}

The results of the Phase 2 analysis are summarized in Tables IX and $X$. These results indicate that:

- If a breakthrough occurs, the options with the best impact and leverage are, in descending order:

- an immediate 25 percent keyed-to-breakeven subsidy

- an immediate 50 percent keyed-to-breakeven subsidy or a breakthrough-dependent Federal purchase of $50 \mathrm{MWp}$

- an immediate 30 percent uniform price reduction or an immediate Federal purchase of $50 \mathrm{MWp}$

- If a breakthrough does not occur, the immediate incentives with the best potential are, in descending order:

- a 75 percent keyed-to-breakeven subsidy

- a 50 percent keyed-to-breakeven subsidy

- a Federal purchase of $1000 \mathrm{MWp}$

- An immediate 50 percent keyed-to-breakeven subsidy would have high impact and leverage; with or without a breakthrough.

As indicated in TablesII and III, the range of results from the

Phase 2 analysis is relatively small. This suggests that:

- The relative impact and leverage of the Federal options may be dependent upon the assumptions used in the model. 
TABLE IX

SUMARY OF PHASB 2 ANALYSIS - BREAKTBROUGH CASES

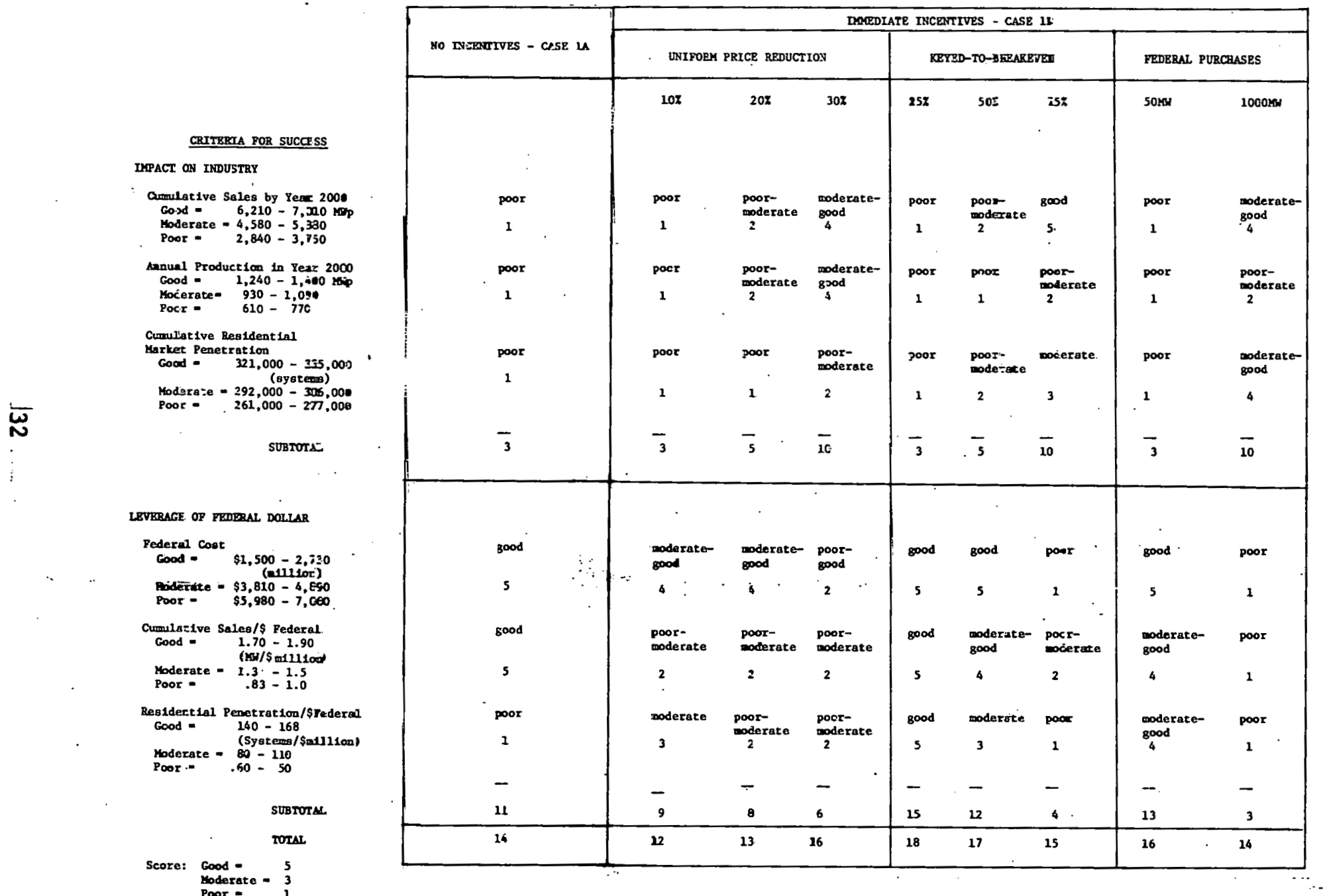


TABLE IX, concluded

SUMMARY OF PHASE 2 ANALYSIS-BRRAKTHROUGH CASES

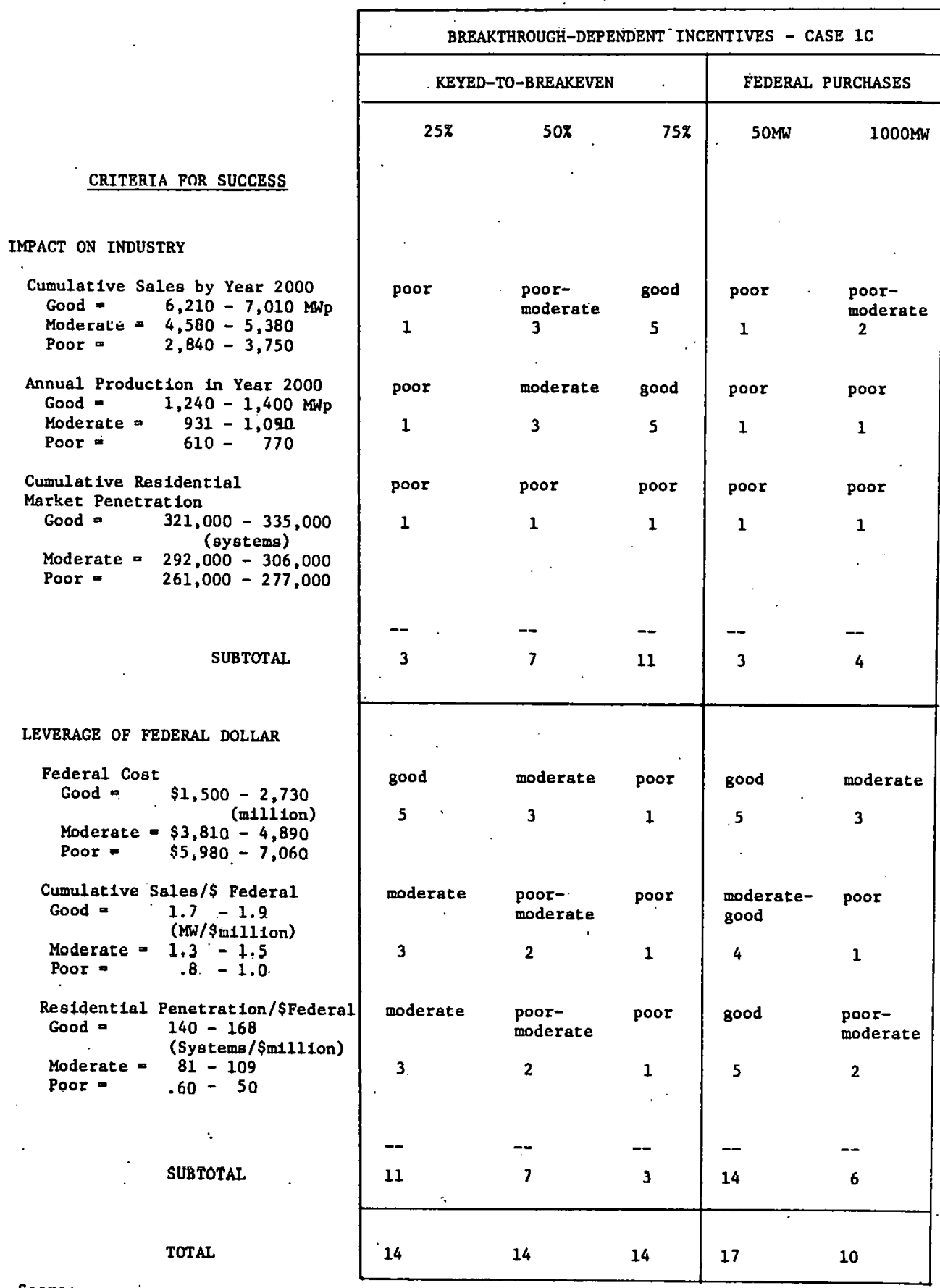

Score:

Good - 5

Moderate a 3

Poor $=1$ 
TABLE $X$

SUMARARY OF ?BASR 2 ANALYSIS - MON-BREAKTEROUGH CASB

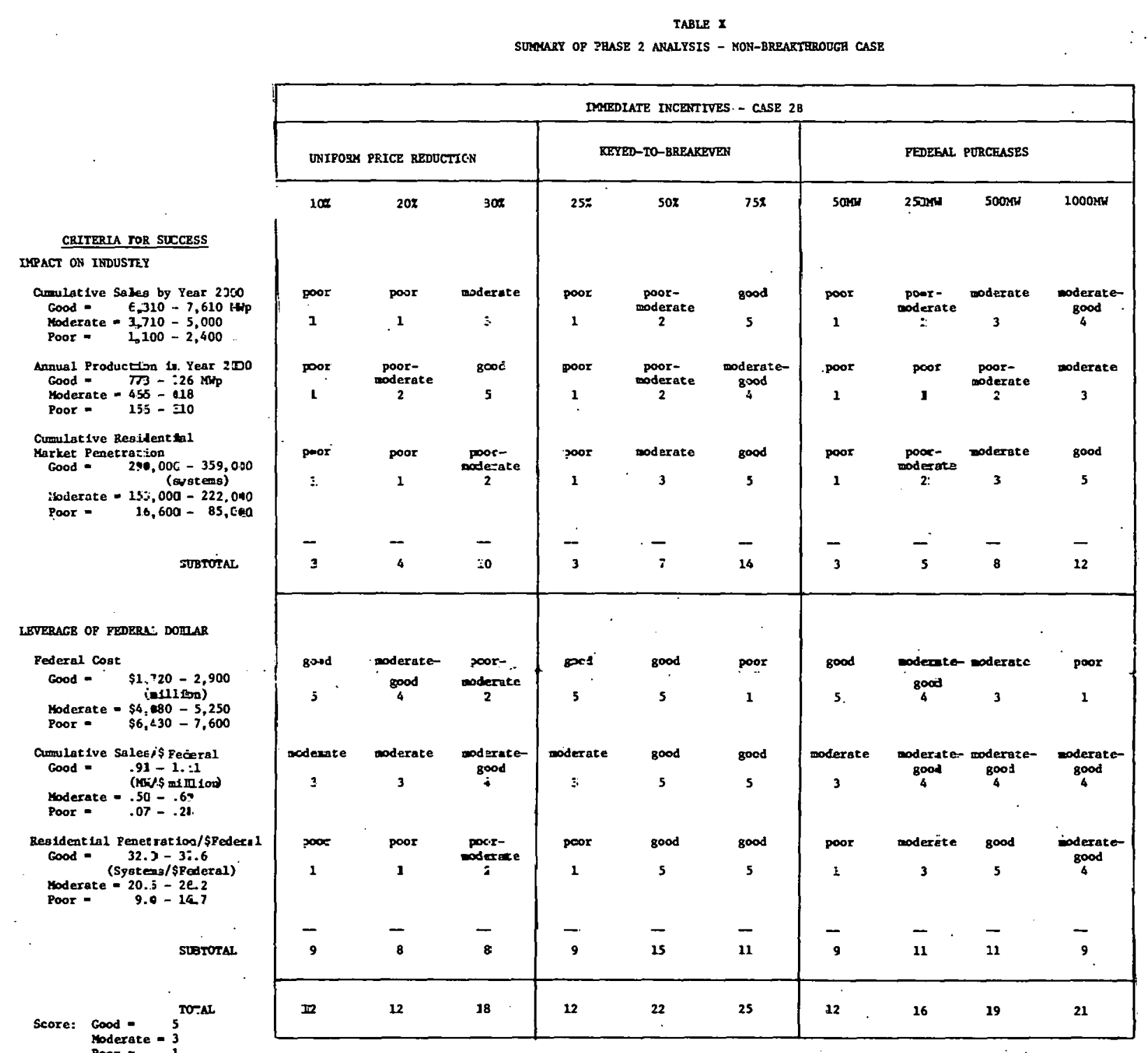

soderate -3
Poor -1 
- Qualitative and quantitative analyses are necessary to identify the best of the more promising options.

MITRE recognizes that Federal cost assumptions must be improved to provide a more accurate estimate of Federal leverage. However, administrative costs are a major uncertainty. These costs could vary greatly, depending upon the mechanism chosen to deliver each option. For this reason, estimates of Federal costs were limited to forgone revenues in the direct price reduction and keyed-to-breakeven subsidies, and were limited to the price of equipment in the Federal purchase options.* If administrative costs had been included, the relative leverage of the options could be different.

Administrative costs are closely related to qualitative aspects, such as ease of implementing an incentive, or industrial decision processes. The administrative costs and qualitative aspects associated with the three types of incentive options are summarized in Table XI. However, each option must be analyzed further before a conclusion on "best incentive" can be made.

\footnotetext{
"The cost of the existing Federal program was assumed to be $\$ 1.5$ billion for the years 1980 to 1990 . (Federal costs were derived from the "Solar Photovoltaic Energy Research, Development and Demonstration Act of 1978.") These costs were added to the cost of direct price reductions and keyed-to-breakeven subsidies in Cases $1 B, 1 C$ and $2 B$.
} 
TABLE XI

QUALITATIVE ASSESSMENT OF OPTIONS

\begin{tabular}{|c|c|c|}
\hline INCENTIVE OPTION & $\begin{array}{c}\text { RELATIVE } \\
\text { ADMINISTRATIVE } \\
\text { COST } \\
\end{array}$ & EASE OF IMPLEMENTATION \\
\hline Uniform Price Reduction & Moderate & $\begin{array}{l}\text { + Relatively simple to administer (i.e., tax } \\
\text { credit or deduction) } \\
+ \text { Would encourage industry to achieve lowest } \\
\text { possible prices. (Iacentive could be applied } \\
\text { even if breakeven costs have been achieved.) }\end{array}$ \\
\hline Keyed-to-Breakeven Subsidy & High & $\begin{array}{l}\text { - Difficult to administer. Would require expen- } \\
\text { sive, continuous assessment to establish } \\
\text { breakeven prices. } \\
\text { + Foregone Federal revenues would decrease as } \\
\text { technology improves. Incentive can be gradu- } \\
\text { ally "phased-out." } \\
\text { - May not encourage industry to achieve } \\
\text { better-than-breakeven prices. }\end{array}$ \\
\hline Federal Purchase & Low & $\begin{array}{l}\text { +. Near-term impact would be sibstantial because } \\
\text { purchases would represent a large portion of } \\
\text { the total market. } \\
\text { - Large impact may require focuaing incentive } \\
\text { on a limited number of manufacturers. May } \\
\text { reduce competition. } \\
\text { - Uncertain long-range impact. System design } \\
\text { and cost would be geared to government } \\
\text { requirements rather than private market } \\
\text { demand. }\end{array}$ \\
\hline
\end{tabular}




\subsection{PHASE 3 ANALYSIS: TESTING OF ASSUMPTIONS}

Comments on earlier drafts of this report indicate that the most controversial MITRE assumptions concerned market estimates and methods for modeling reductions in the price of photovoltaic technology. Phase 3 of this analysis was performed to determine how alternative assumptions in each of these areas would impact results from Phases 1 and 2.

\subsection{Modeling Methodology}

In Phases 1 and 2 of this analysis, experience curves were used to generate the price of technology as a function of cumulative production experience. In Phase 3 , the model was altered so that market and industry response could be calculated, assuming that the following DOE price goals are achieved:

$\begin{array}{cc}\text { Year } & \text { FOB Factory } \\ & (1975 \text { Dollars } \\ 1982 & \\ 1983 & 2.00 \\ 1986 & 1.00 \\ 1990 & .10^{.50}-.30\end{array}$

As shown on Table XII, the results from Llie use of DOE price goals are very similar to results from the use of experience curves, assuming a breakthrough and no incentives. This indicates that:

- DOE price goals are probably achievable, without incentives, if a technological breakthrough occurs. Achievement of the goals would require markets, such as those used in this analysis, that are large enough to justify large-scale production of breakthrough technology. 
TABZB XII

TEST OP ASSUAPTIOHS - PBICE REDCTION RETHOTS:

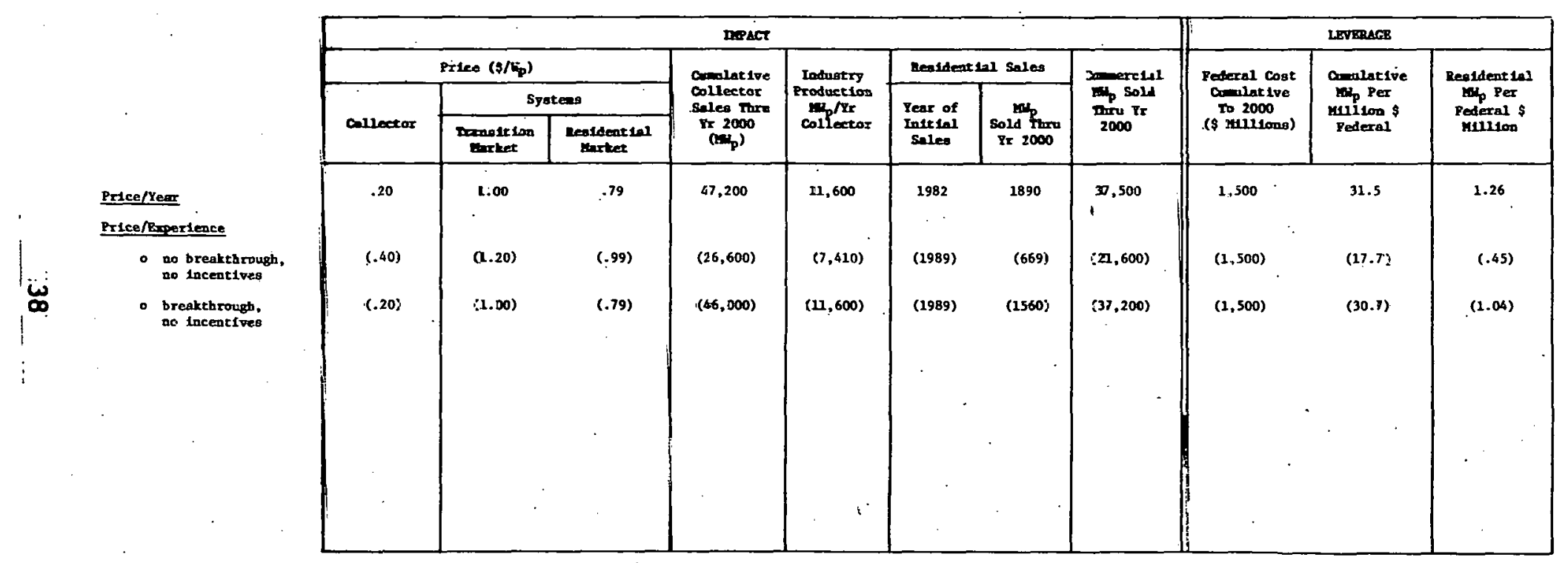

Ancludes residentsal, connerclal, and at llity mass mirkets. 


\subsection{Market Assumptions}

\subsubsection{Commercial and Utility Mass Markets}

In Phase 3 of the analysis, commercial and utility mass markets were added to the photovoltaic incentive model. (Only transition markets and residential mass markets were modeled in Phases 1 and 2.) Estimates of the commerical and utility markets, summarized in Section 3, were derived from the SPURR* market penetration model.

Results from the Phase 3 analysis are summarized in Tables XIII and XIV. These results indicate that with an aggressive Federal $R$ and D program, and without incentives:

- Increased markets yielded an increase in impact and leverage of Federal expenditures;

- The results from a breakthrough remain substantially larger than nonbreakthrough results;

- The inclusion of additional markets has the greatest effect if there is no breakthrough. This is because price reductions in the nonbreakthrough case occur solely as a function of production experience and market pull. Price reductions in a breakthrough case are less market dependent. Prices will be reduced, regardless of the market size.

With an aggressive Federal $R$ and $D$ program, incentives and no

breakthrough:

- A 30 percent uniform price reduction has a much larger impact than the other incentives. However, the Federal cost of the incentive is prohibitive. These results occur because the 30 percent uniform price reduction is the only incentive tested in Phase 3 that remains in effect after 1990 and because a large purtion of the Fcderal expenditure was used to subsidize systems that were already economically competitive.

\footnotetext{
'System for Projecting Utilization of Renewable Resources (SPURR), The MITRE Corporation, Metrek Division, 1978.
} 
TABLE XIII

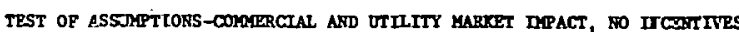

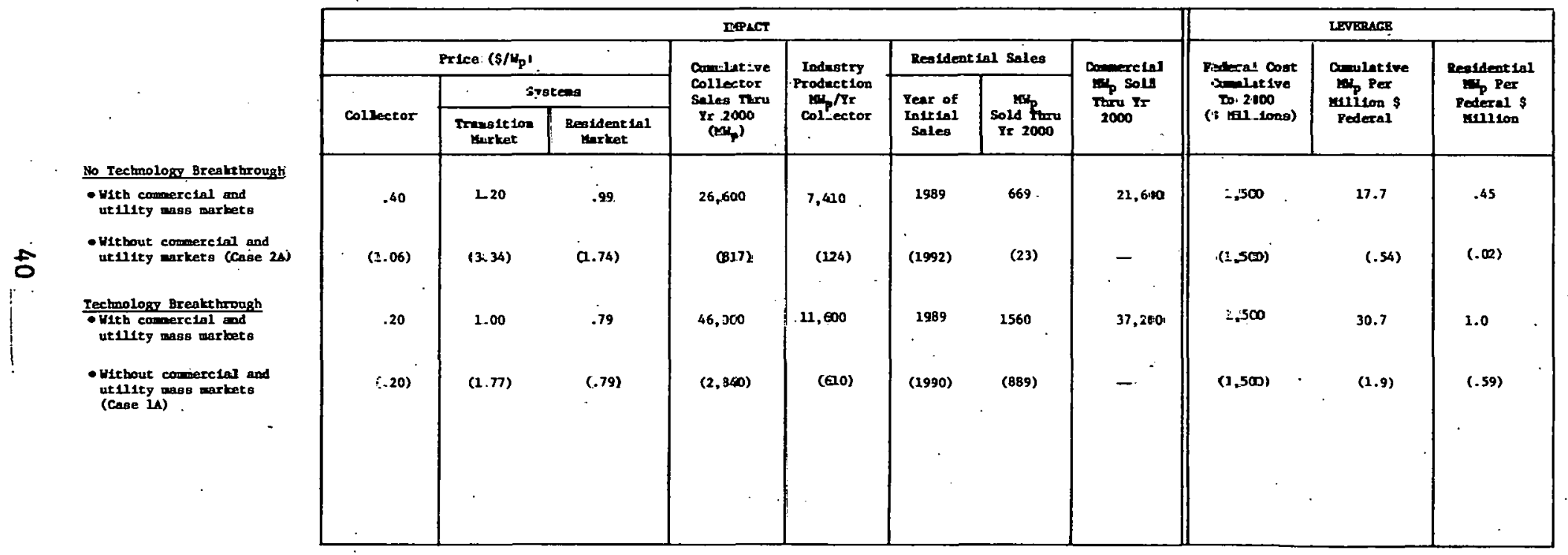


TABLE XIV

TEST OF ASSURPTIONS-CONERCLAL AND UTIITY MARKET IMPACT,

NO BRRAKTHROUGH, GITH DMTEDIATE DNCENTIVES

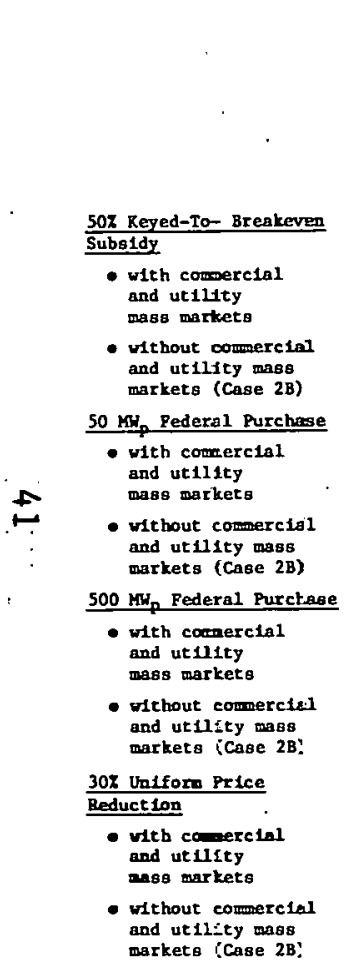

\begin{tabular}{|c|c|c|c|c|c|c|c|c|c|c|}
\hline \multicolumn{8}{|c|}{ IMPACT } & \multicolumn{3}{|c|}{ LEVERAGE } \\
\hline \multicolumn{3}{|c|}{ Price $\left(s / l_{p}\right)$} & \multirow{3}{*}{$\begin{array}{l}\text { Cummulative } \\
\text { Collector } \\
\text { Sales Thru } \\
\text { Yr 2000 } \\
\text { (NWW })\end{array}$} & \multirow{3}{*}{$\begin{array}{c}\text { Industry } \\
\text { Product1on } \\
\text { Malp/7r } \\
\text { collector }\end{array}$} & \multicolumn{2}{|c|}{ Realdential Salea } & \multirow{3}{*}{$\begin{array}{l}\text { Commerc lal } \\
\text { mip Sold } \\
\text { Thru Yr } \\
2000\end{array}$} & \multirow{3}{*}{$\begin{array}{l}\text { Pederal Cost } \\
\text { Oerulat 1ve } \\
\text { To } 2000 \\
\text { (\$ H11110ns) }\end{array}$} & \multirow{3}{*}{$\begin{array}{l}\text { Cumulative } \\
\text { mup Per } \\
\text { Million } \$ \\
\text { Pederal }\end{array}$} & \multirow{3}{*}{ 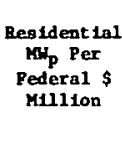 } \\
\hline & & & & & Year of & $\mathrm{nw}_{\mathrm{p}}$ & & & & \\
\hline Collector & $\begin{array}{l}\text { Transit Lon } \\
\text { market }\end{array}$ & $\begin{array}{l}\text { Residenctal } \\
\text { Market }\end{array}$ & & & $\begin{array}{l}\text { InItina } \\
\text { Sales }\end{array}$ & $\begin{array}{l}\text { Sold Thru } \\
\text { Yr 2000 }\end{array}$ & & & & \\
\hline .39 & 1.19 & 8و & 30,800 & 7,480 & 1981 & 1200 & 23,800 & 5,540 & 5.56 & .22 \\
\hline (.64) & (2.19) & (1.23) & $(2,620)$ & (316) & (1998) & (31.3) & - & $(2,760)$ & (.95) & (.11) \\
\hline .39 & 1.19 & .98 & 27,400 & $3,780^{\circ}$ & 1988 & 727 & 22,000 & 2,000 & 13.7 & .36 \\
\hline (.89) & (2.89) & (1.48) & $(1,220)$ & (171). & (1989) & (80) & - & $(2,030)$ & $(. \in 0)$ & $(.06)$ \\
\hline .39 & 1.19 & .98. & 30,000 & 7,460 & 1984 & 902 & 23,200 & 4,440 & 6.76 & .20 \\
\hline (.55) & (1.92) & (1.14) & $(3,830)$ & (432) & (1984) & (518) & - & 4.750 & (.81) & .11 \\
\hline .35 & 1.15 & .94 & 61,900 & 16.100 & $198:$ & 1900 & 50,400 & $2 i, 000$ & 2.29 & .07 \\
\hline$(.53)$ & (1.86) & (1.12) & $(4,650)$ & (926) & (1989) & (333) & - & $(5,530)$ & $(.84)$ & .06 \\
\hline
\end{tabular}


- The tested incentives were not able to reduce photovoltaic prices sufficiently to achieve utility mass market penetration in these simulations by the year 2000 .

\subsubsection{SERI Market Impact}

MITRE estimates of transition and residential markets were replaced by SERI's estimates of small and very large markets.* As shown below, MITRE's total market estimate is more than twice as large as the SERI very large market. However, a muoh larger proportion of the SERI markets have high breakeven prices.

SERI AND MITRE MARKET SIZE

\begin{tabular}{cccc}
$\begin{array}{c}\text { BREAKEVEN LIFE-CYCLE } \\
\text { SYSTEM PRICE } \\
\begin{array}{c}\text { (1986 prices in 1975 } \\
\text { dollars per Wp) }\end{array}\end{array}$ & $\begin{array}{c}\text { SERI SMALL } \\
\text { MARKETS } \\
\text { (MWp/Yr) }\end{array}$ & $\begin{array}{c}\text { SERI VERY LARGE } \\
\text { MARKETS } \\
(\text { MWp/Yr) }\end{array}$ & $\begin{array}{c}\text { MARKETS ESTI- } \\
\text { MATED BY MITRE } \\
\text { (MWp/Yr) }\end{array}$ \\
\hline 20 & 0 & 19 & 3 \\
$10-20$ & 6 & 10 & 5 \\
$5-9.9$ & 6 & 206 & 5 \\
$1-4.9$ & 27 & 451 & 330 \\
1 or less & $\frac{2535}{2574}$ & $\frac{2986}{3672}$ & $7315^{* *}$ \\
Total & & & 7658
\end{tabular}

The Phase 3 resulls iu Table XV indicace that the impact and leverage would be greater for the SERI Very Large Market than for the MITRE market estimate. This occurs because most of the market penetration is in the higher-priced transition markets which are much *Solar Energy Research Institute, Final Report--Photovoltuic Venture Analysis, SERI/TR-52-040, July 1978.

**Includes a residential market of 1265 MWp per year. 
TABLE XV

TEST OF ASSU:PTTIONS - SERI MARKETS, AGGRESSIVE FEDERAL RSD, NO INCENTIVES, NO BREARTHRODGH

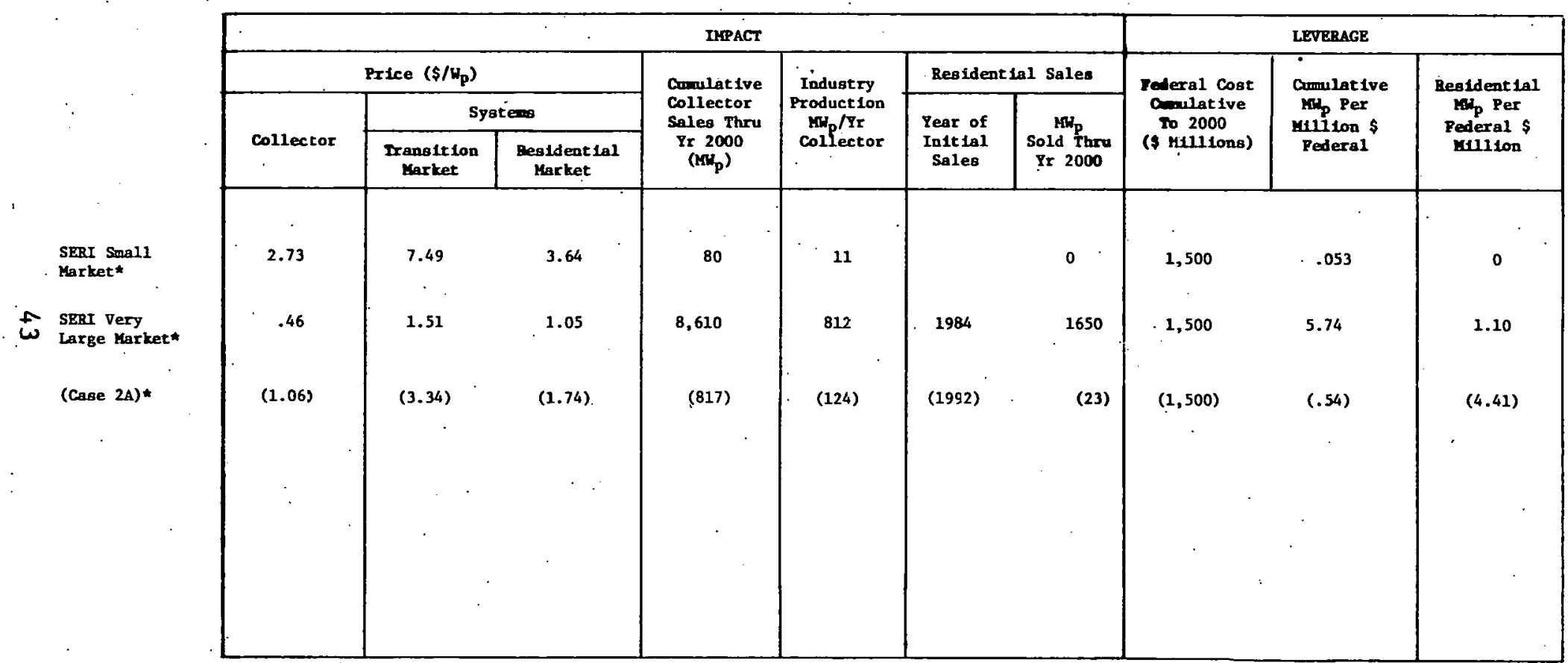

* No commercial or ut1lity nass markets 
larger in the SERI Very Large Market estimates. If the simulation had been extended beyond the year 2000 , the analysis results would reflect increased penetration of the mass market, and it would be likely that the impact and leverage using MITRE's market estimate would be larger than the results using SERI markets. 
APPENDIX A

ANALYSIS RESULTS

$$
\text { A-1 }
$$


ANAIYSIS RESULTS - CASE 1A (AGGRESSIVE FRDERAL R\&D, BRRAKTHROUGR, NO INGENIIVES)

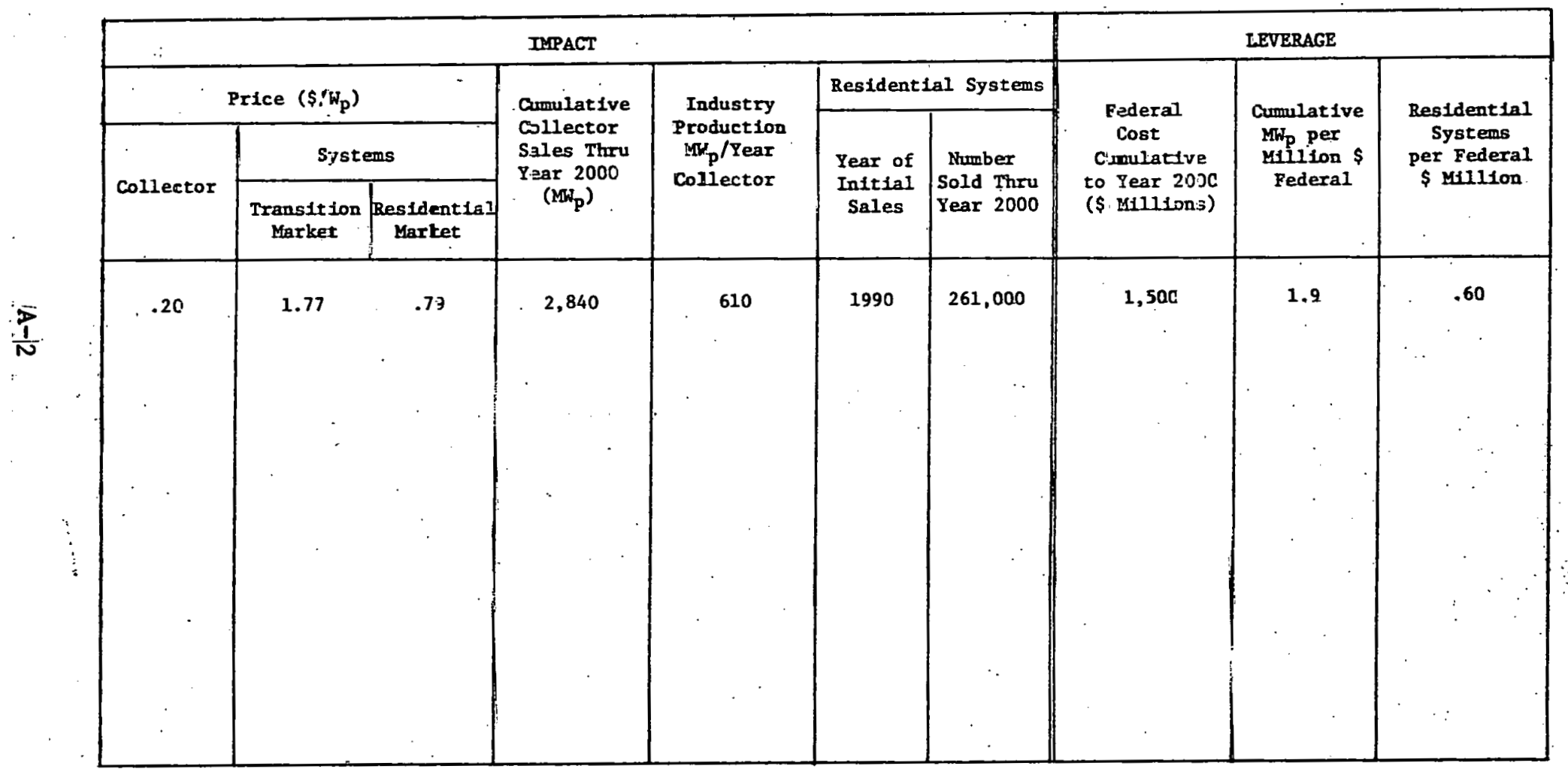


ANALYSIS BRSULTS - CASE 1B (AGGRESSIVE FEDERAI RED, BREAKTHROUGB, DMMEDIATE INCENTIVES)

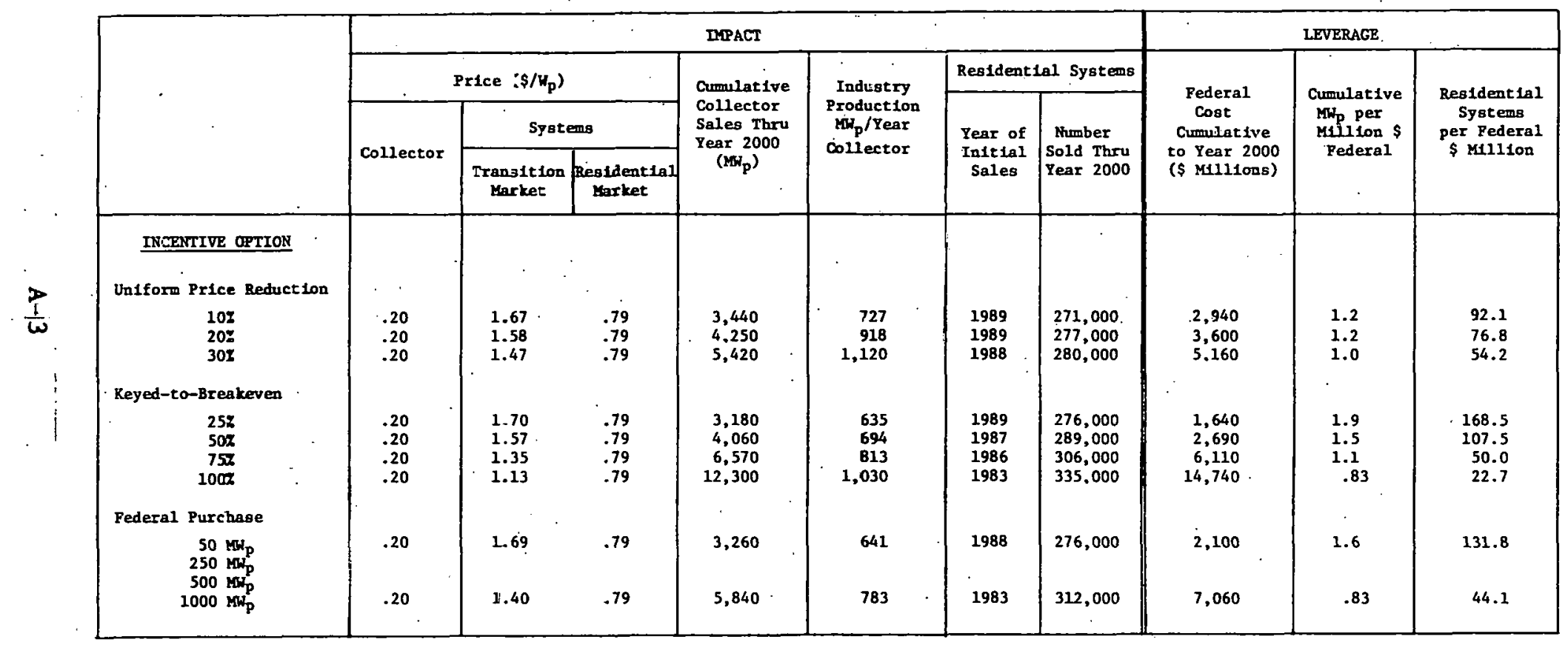


ANALYSIS RESULTS - CASE 1C CARGRESSIVE PEDERAL RAD, BRRAKTHROUGZ-DEPENDERT: INCENITVES)

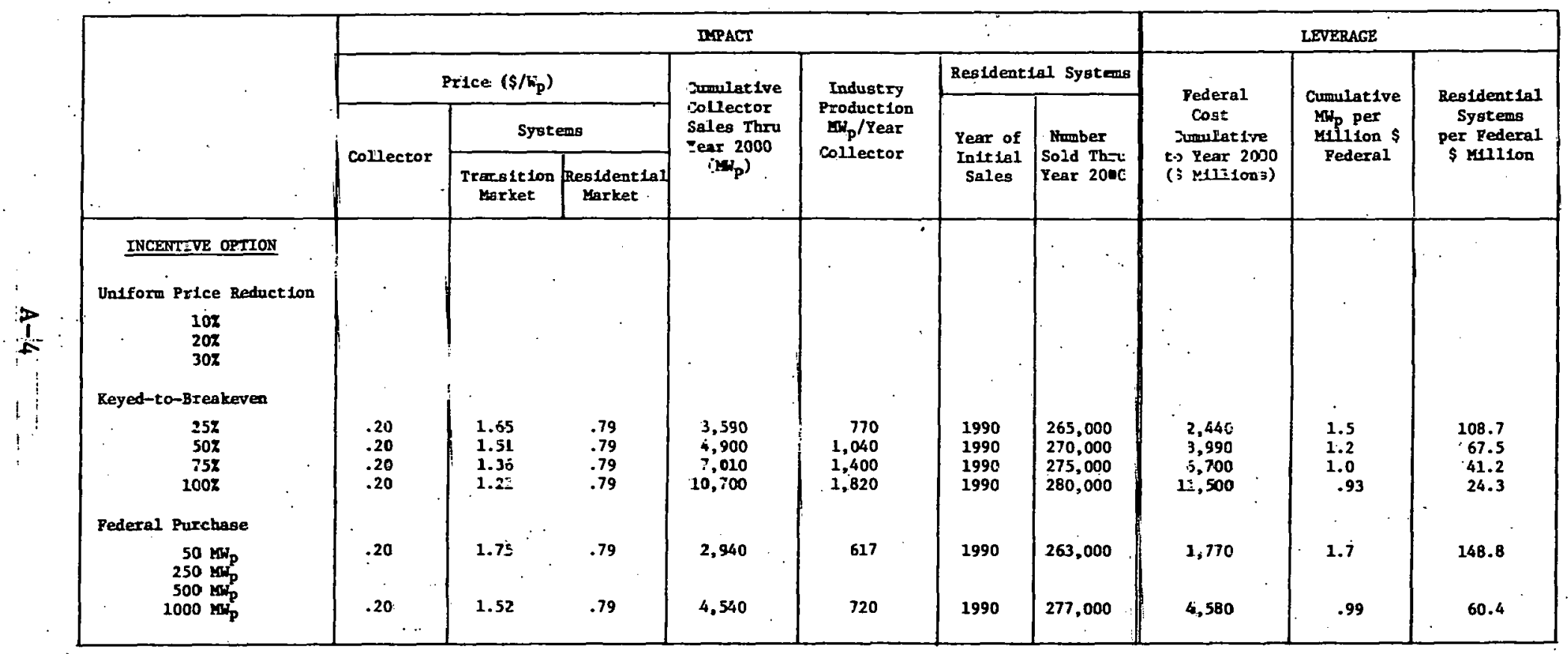


ANALYSIS RESULTS - CASE 2A (AGGRESSIVE FEDERAL R\&D, NO BREAKTBROUGH, NO INCENTIVES)

\begin{tabular}{|c|c|c|c|c|c|c|c|c|c|}
\hline \multicolumn{7}{|c|}{ IMPACT } & \multicolumn{3}{|c|}{ LEVERAGE } \\
\hline \multicolumn{3}{|c|}{ Price $\left(\$ / W_{p}\right)$} & \multirow{3}{*}{$\begin{array}{l}\text { Cumulative } \\
\text { Collector } \\
\text { Sales Thru } \\
\text { Year } 2000 \\
\text { (MW }) \text {. }\end{array}$} & \multirow{3}{*}{$\begin{array}{c}\text { Industry } \\
\text { Production } \\
\text { MW }_{\mathrm{p}} / \text { Year } \\
\text { Collector }\end{array}$} & \multicolumn{2}{|c|}{ Residential Systems } & \multirow{3}{*}{$\begin{array}{c}\text { Federal } \\
\text { Cost } \\
\text { Cumulative } \\
\text { to Year 2000 } \\
\text { (\$ M11110ns) }\end{array}$} & \multirow{3}{*}{$\begin{array}{l}\text { Cumulative } \\
\text { MWp per } \\
\text { Mallion } \$ \\
\text { Federal }\end{array}$} & \multirow{3}{*}{$\begin{array}{c}\text { Residential } \\
\text { Systems } \\
\text { per Federal } \\
\$ \text { Million } \\
.\end{array}$} \\
\hline \multirow{2}{*}{ Collector } & \multicolumn{2}{|c|}{ Systems } & & & \multirow{2}{*}{$\begin{array}{c}\text { Year of } \\
\text { Inftial } \\
\text { Sales }\end{array}$} & \multirow{2}{*}{$\begin{array}{l}\text { Number } \\
\text { Sold Thru } \\
\text { Year } 2000\end{array}$} & & & \\
\hline & $\begin{array}{c}\text { Transition } \\
\text { Market }\end{array}$ & $\begin{array}{l}\text { Residential } \\
\text { Market }\end{array}$ & & & & & & & \\
\hline 1.06 & 3.34 & 1.74 & 817 & 124 & 1992 & 6,620 & 1500 & .54 & 4.4 \\
\hline & & & & & & & & & \\
\hline & & 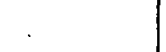 & & & & & & & \\
\hline & & & & & & & & & \\
\hline & & & & & & & & & \\
\hline & & & & & & & & & \\
\hline
\end{tabular}


ARALYSIS ERSUTTS - CASE 2B (AGGERSSTVE FELERAL RED, NO BRRAKTHRODGB, IMMEDIATE INCETTITES)

\begin{tabular}{|c|c|c|c|c|c|c|c|c|c|c|}
\hline \multirow{4}{*}{. } & \multicolumn{7}{|c|}{ I.PACT } & \multicolumn{3}{|c|}{ LEVERAGE } \\
\hline & \multicolumn{3}{|c|}{ Price $\left(\$ w_{p}\right)$} & \multirow{3}{*}{$\begin{array}{l}\text { Cumulative } \\
\text { Collector } \\
\text { Salles Thru } \\
\text { Year 2000 } \\
\text { (Xrip) }\end{array}$} & \multirow{3}{*}{$\begin{array}{l}\text { Industry } \\
\text { Production } \\
\text { wow / / ear } \\
\text { collector }\end{array}$} & \multicolumn{2}{|c|}{ Residential Systens } & \multirow{3}{*}{$\begin{array}{l}\text { Federal } \\
\text { Cort } \\
\text { Cunulbat lve } \\
\text { tc. Year 2000 } \\
\text { (s yillions) }\end{array}$} & \multirow{3}{*}{$\begin{array}{l}\text { Cumulative } \\
\text { Map per } \\
\text { Million } \$ \\
\text { Pederal }\end{array}$} & \multirow{3}{*}{$\begin{array}{l}\text { Residential } \\
\text { Systems } \\
\text { per Federal } \\
\$ \text { Million }\end{array}$} \\
\hline & \multirow{2}{*}{ Collector. } & \multicolumn{2}{|c|}{ Systems } & & & Year of & thumber & & & \\
\hline & & $\begin{array}{c}\text { Transilion } \\
\text { Market }\end{array}$ & $\begin{array}{c}\text { Resident } 101 \\
\text { Market }\end{array}$ & & & $\begin{array}{l}\text { Initial } \\
\text { Sales }\end{array}$ & Year 2000 & & & \\
\hline $\begin{array}{l}\text { INCENTTE OPTION } \\
\text { Unlform Price Reduction }\end{array}$ & & & & & $\cdot$ & & & & & \\
\hline $\begin{array}{c}10 z \\
.20 Z \\
30 z \\
\text { Keyed-to-Bzeakeven }\end{array}$ & $\begin{array}{l}.91 \\
.72 \\
.53\end{array}$ & $\begin{array}{l}2.93 \\
2.42 \\
1.86\end{array}$ & $\begin{array}{r}1.50 \\
.1 .31 \\
1.12\end{array}$ & $\begin{array}{l}1,200 \\
2,120 \\
4,650\end{array}$ & $\begin{array}{l}198 \\
388 \\
926\end{array}$ & $\begin{array}{l}1921 \\
1990 \\
1989\end{array}$ & $\begin{array}{l}18,700 \\
40,900 \\
97,900\end{array}$ & $\begin{array}{l}2,060 \\
3,100 \\
5,5=0\end{array}$ & $\begin{array}{l}.58 \\
.68 \\
.84\end{array}$ & $\begin{array}{r}9.1 \\
13.2 \\
17.7\end{array}$ \\
\hline $\begin{array}{r}25 \% \\
50 z \\
75 z \\
1008\end{array}$ & $\begin{array}{l}.93 \\
.64 \\
.46 \\
.41\end{array}$ & $\begin{array}{l}3.00 \\
2.19 \\
1.55 \\
1.26\end{array}$ & $\begin{array}{l}1.53 \\
1.23 \\
1.05 \\
1.00\end{array}$ & $\begin{array}{r}1,100 \\
2,620 \\
7,600 \\
15,000\end{array}$ & $\begin{array}{r}156 \\
316 \\
677 \\
1,020\end{array}$ & $\begin{array}{l}1990 \\
1988 \\
1986 \\
1983\end{array}$ & $\begin{array}{r}16,600 \\
92,100 \\
257,900 \\
353,800\end{array}$ & $\begin{array}{r}1,720 \\
2,760 \\
6,870 \\
16,200\end{array}$ & $\begin{array}{r}.64 \\
.95 \\
1.10 \\
.98\end{array}$ & $\begin{array}{r}9.6 \\
.33 .4 \\
37.6 \\
22.2\end{array}$ \\
\hline 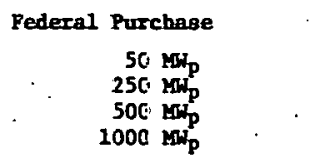 & $\begin{array}{r}.39 \\
.55 \\
. .55 \\
. .48\end{array}$ & $\begin{array}{l}2.89 \\
2.22 \\
1.92 \\
1.67\end{array}$ & $\begin{array}{l}1.48 \\
1.24 \\
1.14 \\
1.07\end{array}$ & $\begin{array}{l}3,220 \\
\geq, 520 \\
3,330 \\
5,840\end{array}$ & $\begin{array}{r}171 \\
307 \\
432 \\
581\end{array}$ & $\begin{array}{l}1989 \\
1985 \\
1984 \\
1983\end{array}$ & $\begin{array}{r}23,300 \\
90,600 \\
152,400 \\
232,100\end{array}$ & $\begin{array}{l}2,030 \\
3,39.3 \\
4,750 \\
7,600\end{array}$ & $\begin{array}{l}.60 \\
.74 \\
.81 \\
.77\end{array}$ & $\begin{array}{l}11.5 \\
26.7 \\
32.1 \\
30.5\end{array}$ \\
\hline
\end{tabular}


ANALYSIS RESULTS - CASE 3A (NO FEDERAL RED, BREAKTHROUGH, NO INCENTIVES)

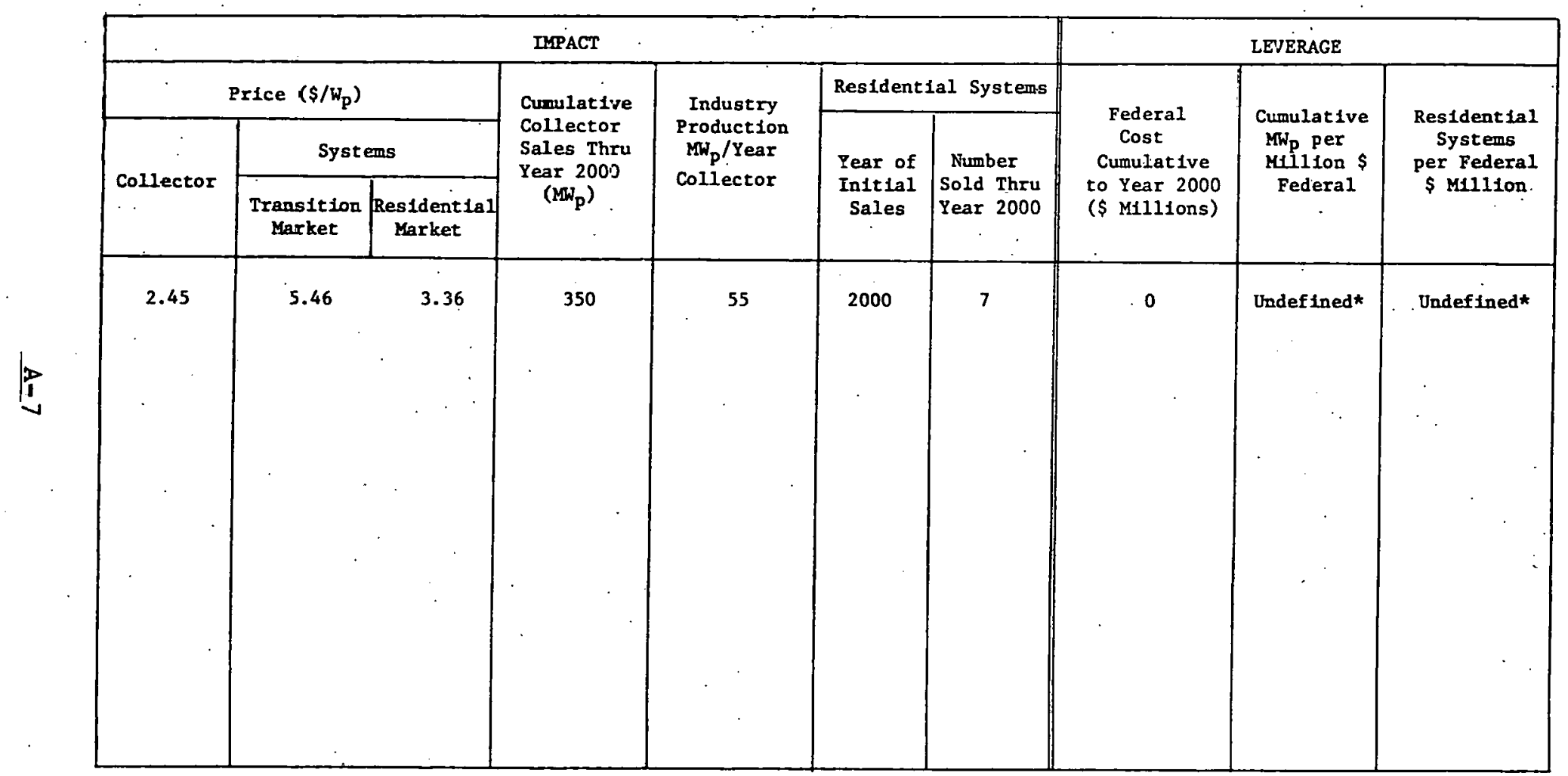

*Denoninator $=0$ 
ANALISTS RESULTS - CASE 3B iNO FEDERAL RED, BREAKTHROUGH, DMRTDLATE INCENTTVES)

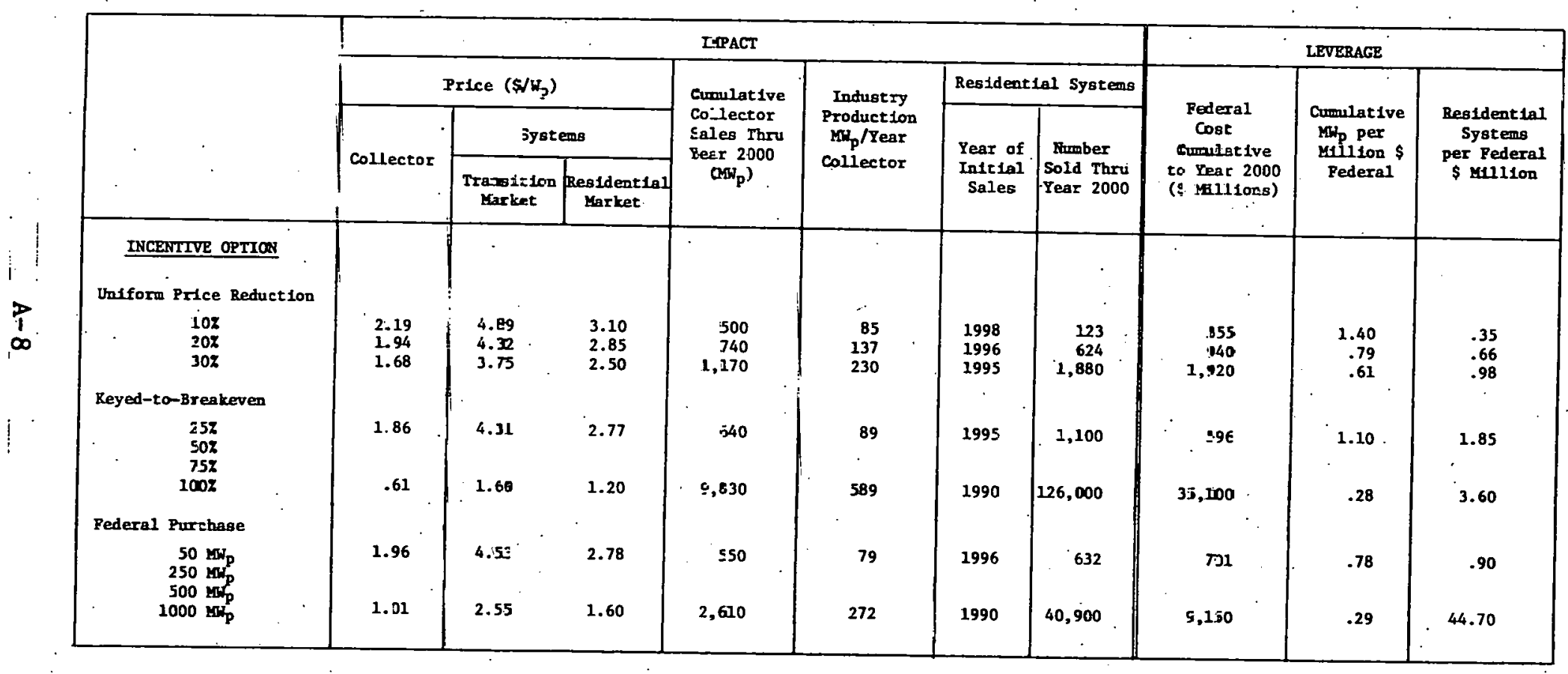


ANALYSIS RESULTS - CASE 3C (NO FEDERAL RED, BREAKTHRCUGH-DEPENDENT INCENTIVES)

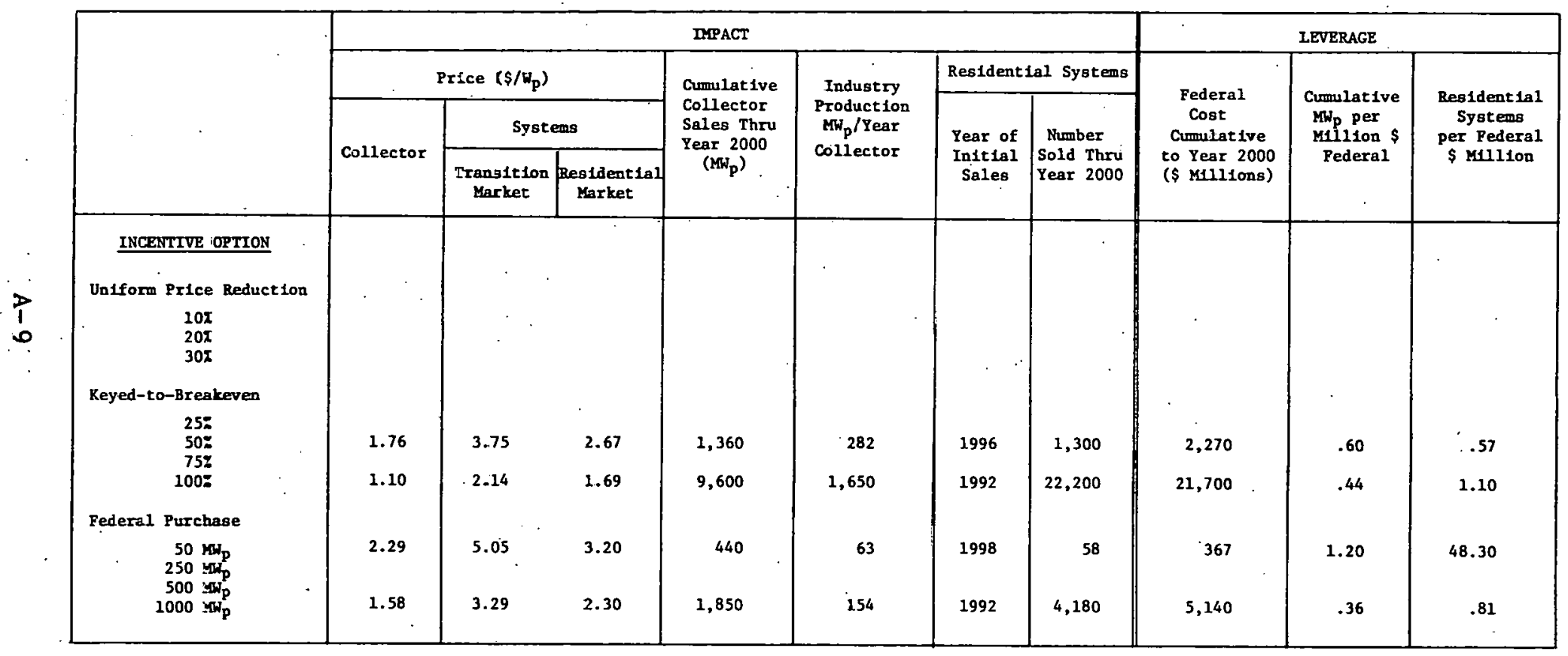


ANALYSIS 3ESULTS - CASE 4A (NO FEDERAL RED, NO BRRAKTHROUGH, NO INCENTIVZS)

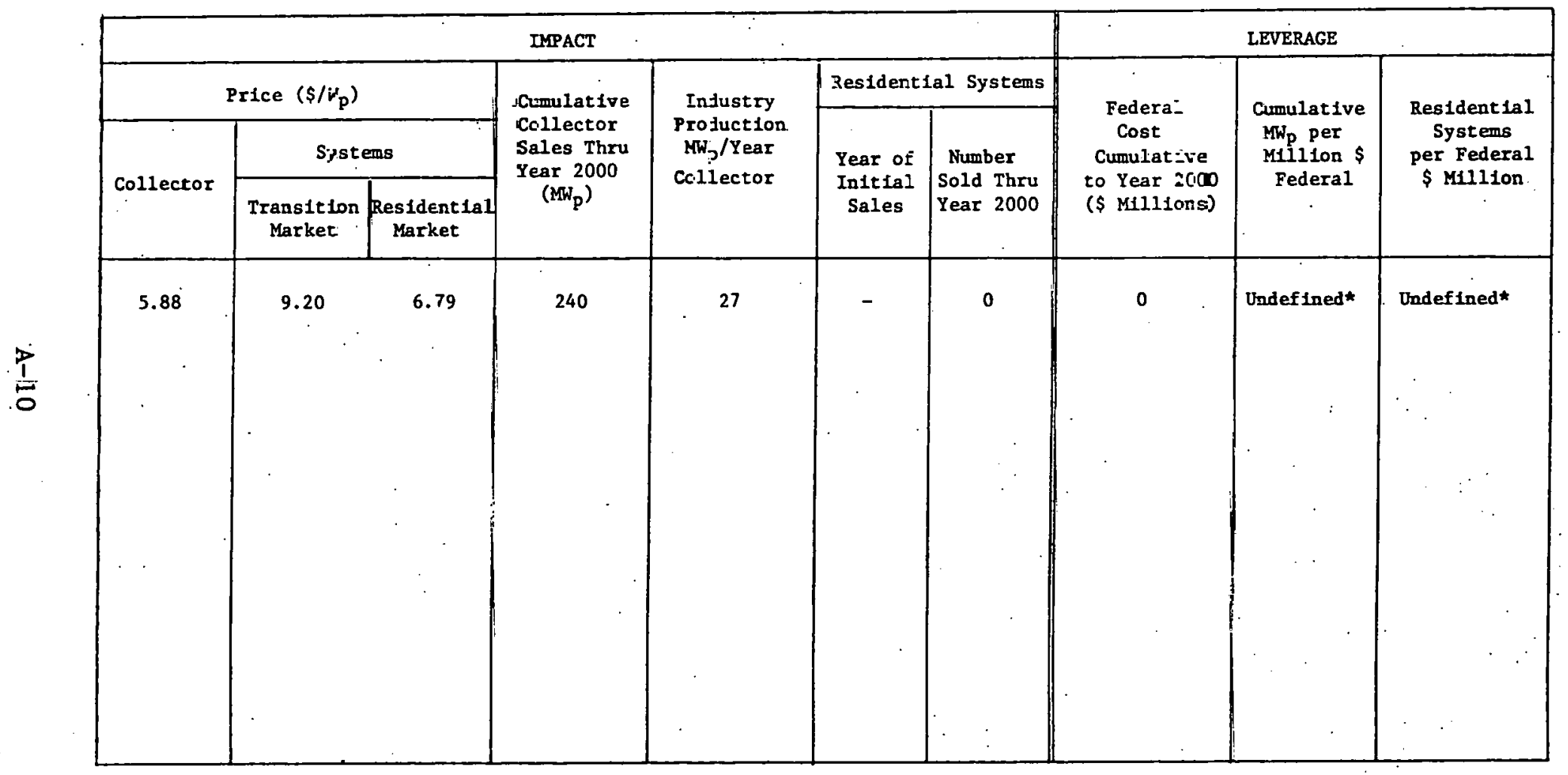

*Denominator $=0$ 
ANALYSIS RESULTS - CASE 4B (NO FEDERAL RED, NO BRRARTHROUCH, TMMEDLATE INCENTIVES)

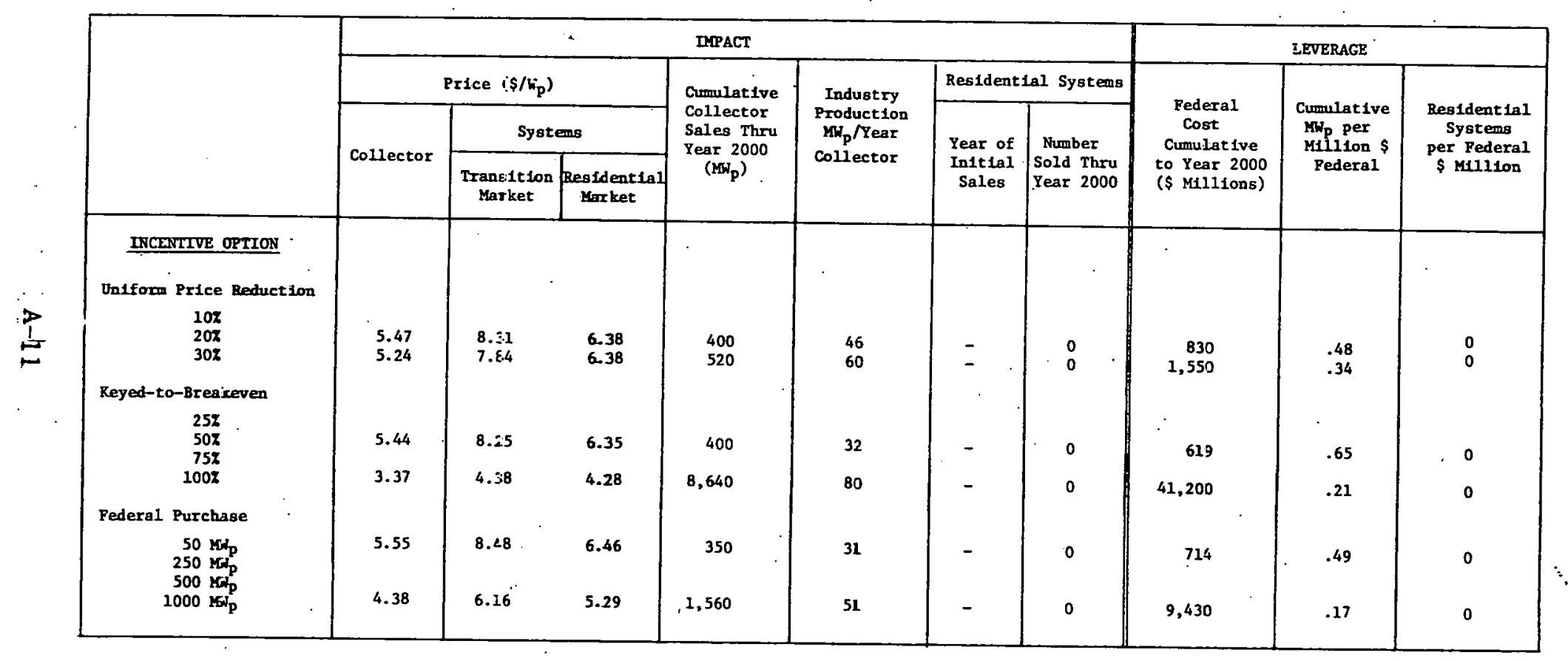


APPENDIX B

MARKET DATA BASE

B-1 
BBYOAL MABKET

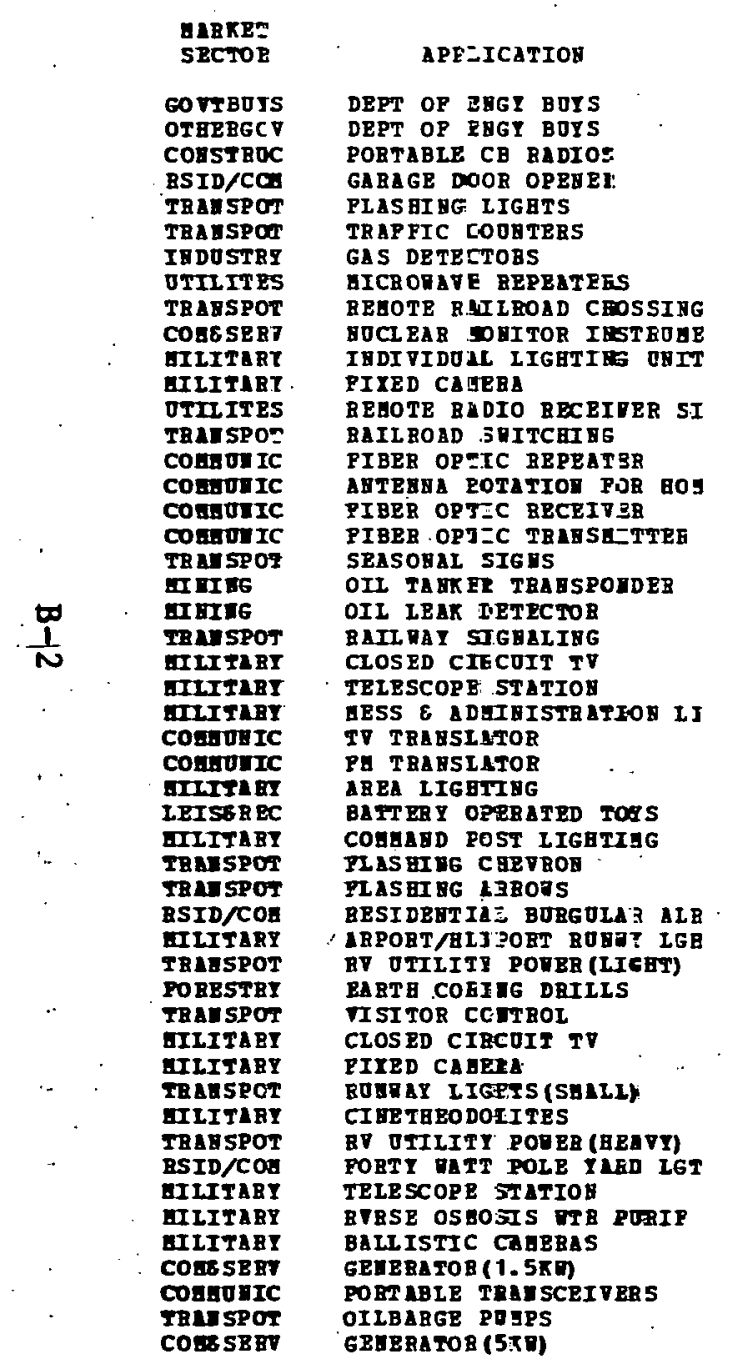

YUBBER OF
SPSTEHS
500000
0
15000
0
300000
1000
4500
1000
2500
11000
100
10
2000
1000
1100
0
2200
2200
1000
72
1500
1000
10
5
26
140
350
80
100000
26
100
100
50000
13
5000
100
200
10
25
1800
30
100
5000
5
200
25
3700
1000000
200
1000

1986 3REAR-EVEH (1975s/RATT)

99999.00

532.00

200.00

168.00

163.55

73.00
72.54
67.25

67.25

58.16

39.00

33.00
29.00

29.00
27.00

27.00

22.76

20.92

19.64

17.03

45. 46

4.00

13.65

13.18

12.20
13.00

9.50

2.58
8.40

6. 31

5.83

5. 70

5.06

5. 00

4.90

4.70

4.51

4.41

4.41

4.00
3.70
3.22

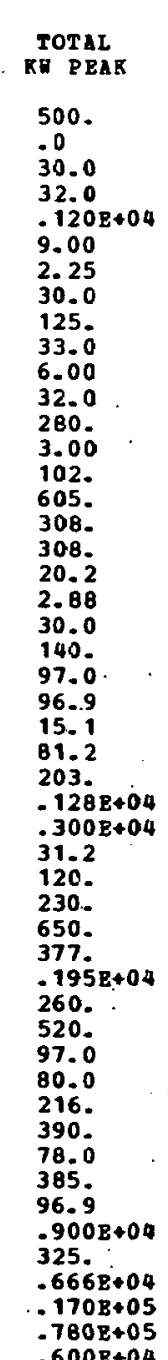

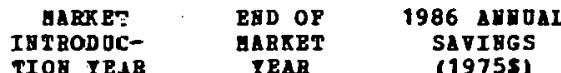

1974
10
1979
1917
1977
1977
1977
1979
1977
1977
1977
1977
1977
1977
1980
1978
1980
19800
1979
1977
1977
1977
1977
1977
1979
1977
1977
1979
1979
1979
1977
1979
1977
1977
1979
1979
1978
1979
1979
1979
1979
1980
1980
1979
1979
1979
1980
1979
1981
1981

0.0
0.0
0.0
0.0
0.0
0.0
0.0
0.0
0.0
0.0
0.0
0.0
0.0
0.0
0.0
0.0
0.0
0.0
0.0
0.0
0.0
0.0
0.0
0.0
0.0
0.0
0.0
0.0
0.0
0.0
0.0
0.0
0.0
0.0
0.0
0.0
0.0
0.0
0.0
0.0
0.0
0.0
0.0
0.0
0.0
0.0
0.0
0.0
0.0
0.0


ANNOAL MARKET

\begin{tabular}{|c|c|c|c|c|}
\hline & $\begin{array}{l}\text { GARKET } \\
\text { SECTOR }\end{array}$ & APPLICATION & $\begin{array}{c}\text { MOMBER OP } \\
\text { SYSTEAS }\end{array}$ & $\begin{array}{l}1986 \text { BREAK-EVEN } \\
\text { LIPE CYCLE PRICE } \\
(1975 \$ / \text { RATT })\end{array}$ \\
\hline $\mathbf{\infty}$ & 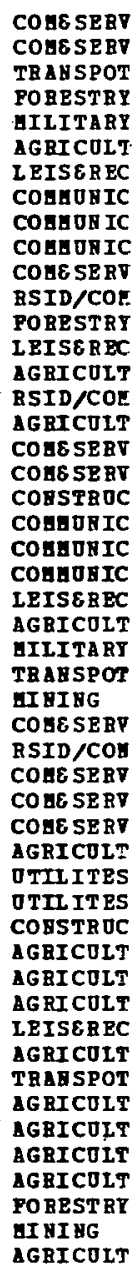 & 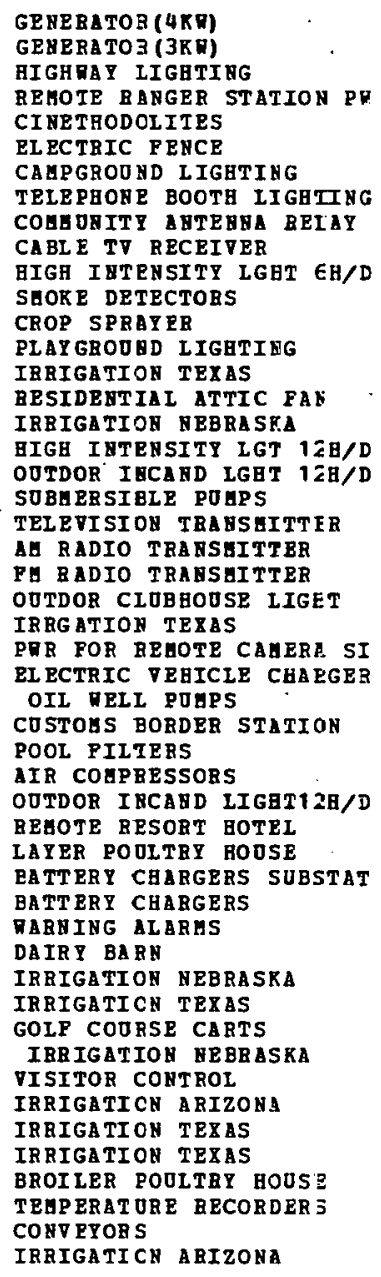 & 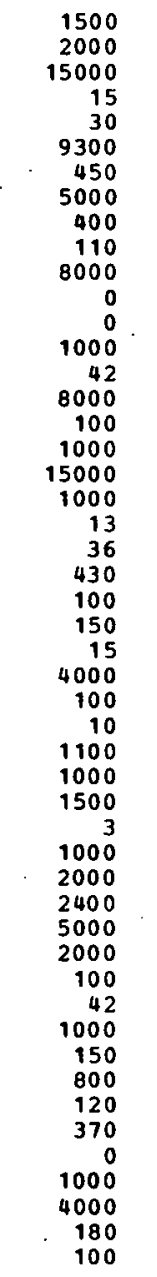 & $\begin{array}{l}3.06 \\
3.02 \\
3.62 \\
2.36 \\
2.36 \\
1.91 \\
1.90 \\
1.71 \\
1.50 \\
1.46 \\
1.46 \\
1.45 \\
1.35 \\
1.35 \\
1.34 \\
1.30 \\
1.15 \\
1.10 \\
1.02 \\
0.99 \\
0.96 \\
0.94 \\
0.94 \\
0.94 \\
0.93 \\
0.90 \\
0.85 \\
0.84 \\
0.83 \\
0.83 \\
0.81 \\
0.80 \\
0.79 \\
0.73 \\
0.68 \\
0.68 \\
0.68 \\
0.65 \\
0.65 \\
0.65 \\
0.65 \\
0.63 \\
0.62 \\
0.61 \\
0.60 \\
0.60 \\
0.60 \\
0.59 \\
0.59 \\
0.59 \\
0.59\end{array}$ \\
\hline
\end{tabular}

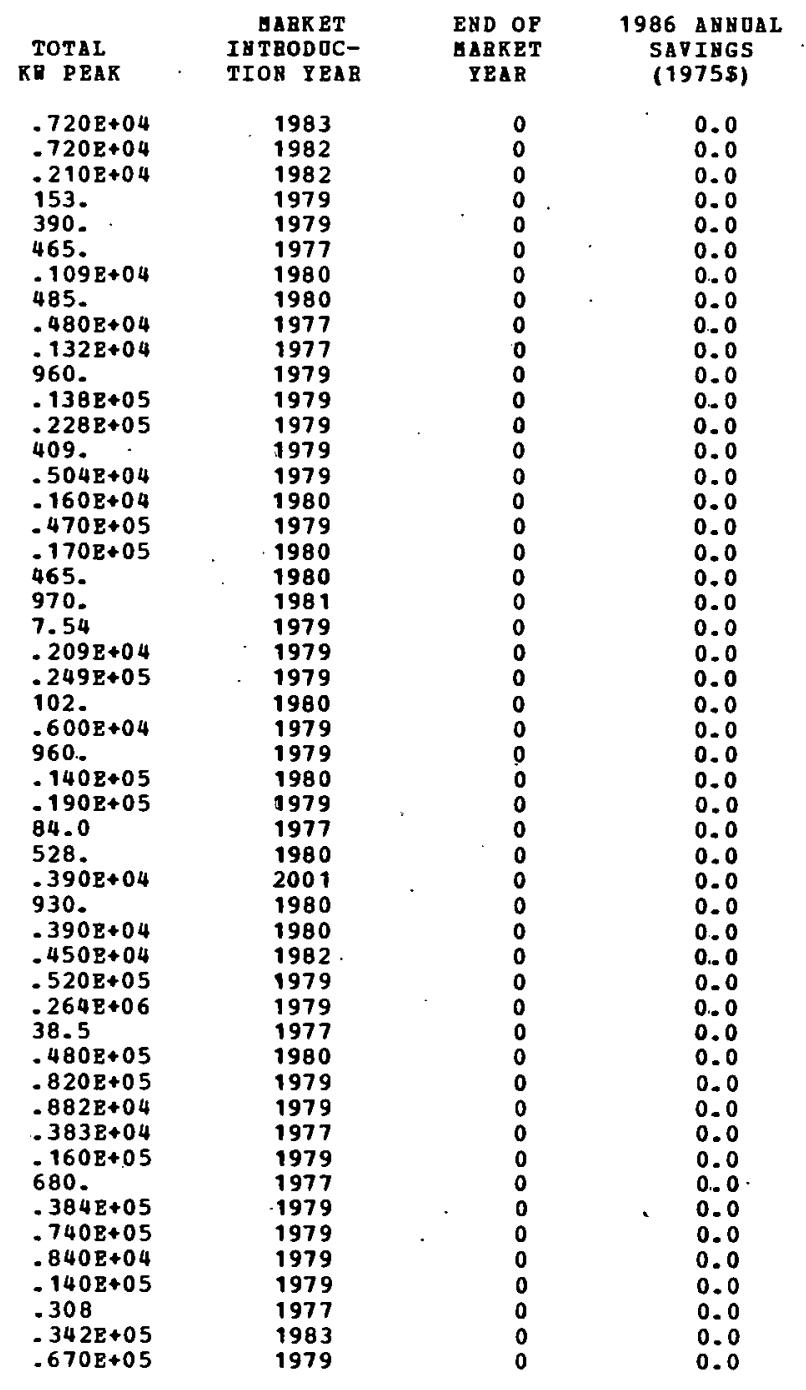


ABMJAL GARKET

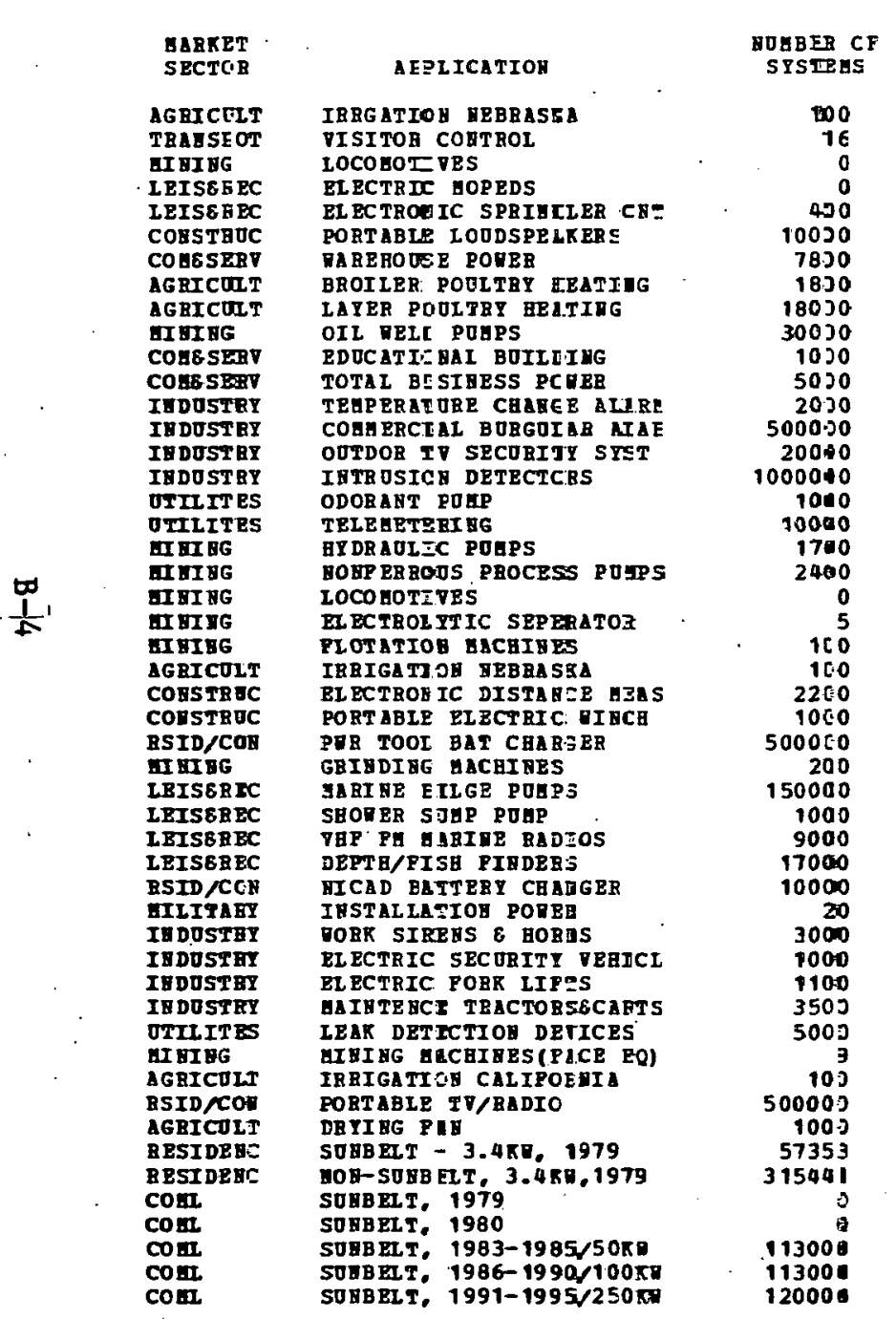

1986 BREAK-EVZB LIPE CPCIE PBIC

TOTAL

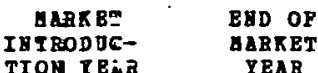

1986 ABBOAL

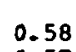

$.630 \mathrm{E}+05$ 8. 48

$.299 \mathrm{E}+06$
$.550 \mathrm{E}+05$

256.

32.0

$.601 E+05$
$.198 E+06$

$.198 \mathrm{E}+06$
$.576 \mathrm{E}+05$

$.300 \mathrm{~B}+07$

$.410 \mathrm{E}+0$

2308+05

16.0 .

$-105 \mathrm{E}+06$

$-116 \mathrm{~B}+05$
$\vdots 100 \mathrm{1}+05$

730.

80.0

$.6638+05$
$.936 \mathrm{~B}+05$

$.2998+06$

$-1958+06$

$-3908+05$
$.2108+05$

$210 \mathrm{z}+05$
50.6

$-130 \mathrm{E}+04$

$-195 E+06$

$.480 \mathrm{~B}+04$

355.

95.0

357.

$800 \mathrm{~B}+06$

.780

$-120 \mathrm{P}+05$

$-1548+05$

500

50.0

$-108 \mathrm{P}+05$
$.130 \mathrm{0}+05$

500 .

$.290 \mathrm{Z}+05$

$.195 \mathrm{E}+06$

$.107 \mathrm{E}+07$

$.5208+08$

0.0

0.85
0.85

0.85
0.85
0.85

$.520 \mathrm{E}+08$
$.565 \mathrm{E}+07$

$.1138+08$

1979

1977

1983
2301

1977

1779

138

1383

1782

1984

1077

1977

1977

1977

1982

1983

1983

1079
1077

1977
1.579

1579

1983

1980

1979

1978

1907

1930
1993

1993
1930

1977

19.33
1930

$1930^{\circ}$

1979
1979

1979

1980
1983

1983
1986
1991

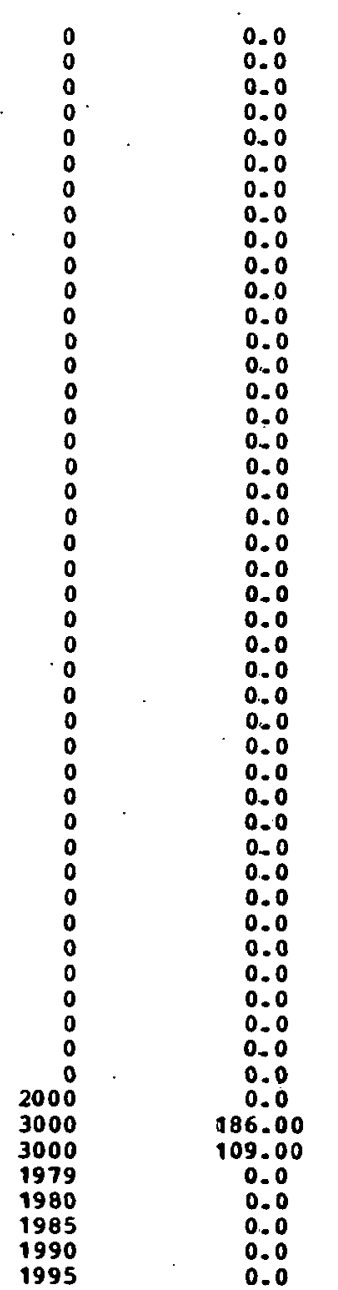




\begin{tabular}{|c|c|c|c|c|c|c|c|}
\hline \multicolumn{8}{|l|}{ 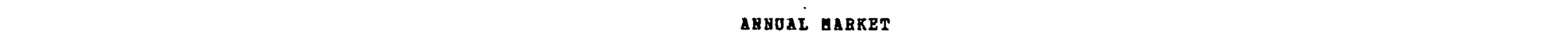 } \\
\hline $\begin{array}{l}\text { BABRPT } \\
\text { SBCTOR }\end{array}$ & APPLICATIOH & $\begin{array}{c}\text { NOABER OF } \\
\text { SYSTEAS }\end{array}$ & 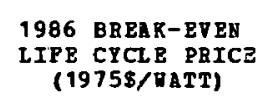 & $\underset{\text { KMI }}{\text { TOTAL }}$ & 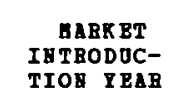 & 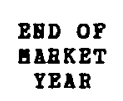 & $\begin{array}{l}1986 \text { ABSOAL } \\
\text { SAVIBGS } \\
\text { (1975s) }\end{array}$ \\
\hline 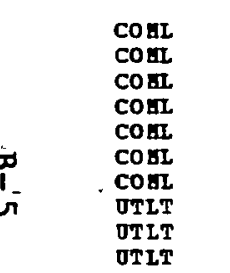 & 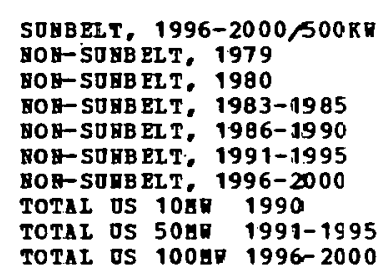 & $\begin{array}{r}127000 \\
0 \\
0 \\
150000 \\
150000 \\
161000 \\
170000 \\
520 \\
128 \\
64\end{array}$ & $\begin{array}{l}0.85 \\
0.74 \\
0.74 \\
0.74 \\
0.74 \\
0.74 \\
0.74 \\
0.47 \\
0.47 \\
0.47\end{array}$ & 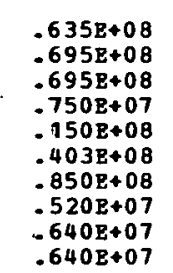 & $\begin{array}{l}1996 \\
1979 \\
1980 \\
1983 \\
1986 \\
1991 \\
1996 \\
1990 \\
1991 \\
1996\end{array}$ & $\begin{array}{l}2000 \\
1979 \\
1980 \\
1985 \\
1990 \\
1995 \\
2000 \\
1990 \\
1995 \\
2000\end{array}$ & $\begin{array}{l}0.0 \\
0.0 \\
0.0 \\
0=0 \\
0.0 \\
0.0 \\
0.0 \\
0.0 \\
0=0 \\
0.0\end{array}$ \\
\hline
\end{tabular}


APPENDIX C

INCENTIVE MECHANISMS

C-1 
APPENDIX C--INCENTIVE MECHANISMS

Table C-I provides examples of mechanisms for incentive options that were modeled in this analysis. This information has been extracted from Photovoltaic Incentives Options, the BDM Corporation, Report W-78-184-TR, August 1978. 
TABLE C-I

EXAMPLES OF INCENTIVE MECHANISMS

\begin{tabular}{|c|c|c|c|c|}
\hline $\begin{array}{l}\text { INCENTIVE OPTIONS } \\
\text { (todeled 1n this } \\
\text { analysis) }\end{array}$ & $\begin{array}{l}\text { MECHANISMS } \\
\text { TO IMPLEMRNT } \\
\text { INCENTIVE. } \\
\end{array}$ & $\begin{array}{l}\text { IMPLEMENTATION } \\
\text { MPTHONS } \\
\end{array}$ & . ADVANTACES & DI SADVANTAGES/PROBLEMS \\
\hline \multirow[t]{4}{*}{ DIRECT PRICR } & - LOW INTEREST LOANS & $\begin{array}{l}\text { - DIRECT LOANS FROM FEDERAL } \\
\text { AGENCIES (SBA? DOE?) } \\
\text { - LOANS THRU BANS OR UTILI- } \\
\text { TIES } \\
\text { - 2-SZ INTEREST RATES, 8-25 } \\
\text { YEARS LOAN MATURTY, ONLY } \\
\text { INTEREST IS SUBSIDIZED }\end{array}$ & $\begin{array}{l}\text { - REDUCE COST OF CAPITAL. } \\
\text { - VERY HIGH LEVERAGE IN } \\
\text { SHORT TERM } \\
\text { - ATTRACTIVE WHEN IMTEREST } \\
\text { RATES HIGH } \\
\text { - EQUITABLE } \\
\\
.\end{array}$ & $\begin{array}{l}\text { - EXPENSIVE TO COVERMRENT } \\
\text { OVER LIPETIME OP PROGRAM } \\
\text { - HIGH ADINISTRATIVE COSTS } \\
\text { - AGENCY DIFPICULTIIS WITH } \\
\text { DIRECT LOAIS --VRRY EXPEN- } \\
\text { SIVE, ENTIRE CAPITAL COST } \\
\text { WOULD HAVE TO COYE PROM } \\
\text { FEDERAL BUDGET } \\
\text { - MAY REQUIRE NEW AUHINIS- } \\
\text { TRATIVE STRUCTURE }\end{array}$ \\
\hline & $\begin{array}{l}\text { - ACCELERATED DEPRECIATION/ } \\
\text { RAPID AMORTIEATION TIED } \\
\text { TO SALES }\end{array}$ & 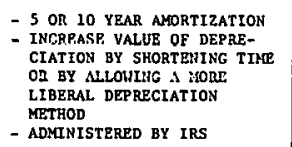 & $\begin{array}{l}\text { - FNCOURAGE INVESTMENT BY } \\
\text { PIRMS HITH LARGE TAXABLE } \\
\text { INCOMES }\end{array}$ & $\begin{array}{l}\text { - WOULD NOT YELP PIRMS WITH } \\
\text { LOH TAXABLE INCOHE } \\
\text { DIFPICULT TO TONTRRDL } \\
\text { PROCRAM SIZE }\end{array}$ \\
\hline & - grants & $\begin{array}{l}\text { - FOR ALL OR PART OF PLANT } \\
\text { OR EQUIPMENT COSTS } \\
\text { - ADHINISTERED BY DOE, SBA } \\
\text { OR CSA } \\
\text { - POR SPECIFIC DEVELORMENT } \\
\text { WORR OR FOR CONSTRUCTION }\end{array}$ & $\begin{array}{l}\text { - DIRECT ECONOMIC BENEFITS } \\
\text { TO MANUFACTURERS, } \\
\text { INSTALLER, DISTRIBUTERS, } \\
\text { SERVICE COEPANIES } \\
\text { - CONPARABLE TO TAX CREDT, } \\
\text { BUT HORE IIMEDLATE AND NO } \\
\text { CHANGE REQUIRED IN TAX } \\
\text { CODE }\end{array}$ & $\begin{array}{l}\text { - HIGH COSTS RELATIVE TO } \\
\text { PROBALE BENEFTS } \\
\text { - LARGE ADKINISTRATIVE } \\
\text { STRUCTURE } \\
\text { - MAY NOT BE EQUITABLE } \\
\text {. }\end{array}$ \\
\hline & $\begin{array}{l}\text { - TAX ACTIONS } \\
\text { - INVESTMENT TAX CREDITS } \\
\text { O CONVENTIONAL } \\
\text { OS YZAR CARRYFORWARD, } \\
2 \text { YEAR CARRYBACK TIED } \\
\text { TO SALES }\end{array}$ & $\begin{array}{l}\text { - ADMINISTERBD BY IRS } \\
\text { - SPECIFY INVESTHENTS THAT } \\
\text { WLL BE CREDTTED; E.G.. } \\
\text { CAYITAL EQ́UTPHENT }\end{array}$ & $\begin{array}{l}\text { - EQUITABLE } \\
\text { - RELAT IVELY HIGH LEVERAGE } \\
\text { - ADMTMISTRATIVELY EPRICIENT } \\
\text { - CAN BE PRECTGFIY TAILORED } \\
\text { FOR SPECIFIC OBJECTIVES }\end{array}$ & 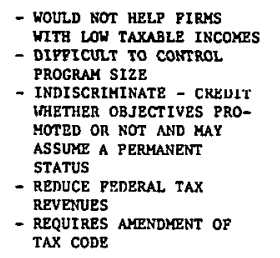 \\
\hline $\begin{array}{l}\text { KEYED-TO-BREAKEVEN } \\
\text { SUBSIDY }\end{array}$ & - PRICE SUPPORTS & $\begin{array}{l}\text { - PAYMENT BY COVERNMENT OP } \\
\text { A DIPFERENTIAL WHEN MARKET } \\
\text { PRICES FALL BELOH A PRE- } \\
\text { DETERMINED SUPPORT LEVEL }\end{array}$ & $\begin{array}{l}\text { - SHIFT RISKS PROM INDUSTRY } \\
\text { TO COVERARENT }\end{array}$ & $\begin{array}{l}\text { - MAY NOT REDUCE RISKS } \\
\text { SUPFICIENTLY TO ATTRACT } \\
\text { BROAD PARTICIPATION } \\
\text { - COULD BE EXPENSIVE } \\
\text { - MAY BE INEQUITABLE, } \\
\text { FAVORING A FEH FIRYLE } \\
\text { - ADMINISTRATIVELY COMPLEX }\end{array}$ \\
\hline FEnERAL PIIRCYHASE & - Federar purchases & $\begin{array}{l}\text { - GOVPRRMERT PURCHASE POR } \\
\text { GOVRRRMENT USE (E.C., FPUP) } \\
\text { - GUARANTEED MARKET AT } \\
\text { STATED PRICE } \\
\text { - GOVERMMENT AS PURCHASER OP } \\
\text { LAST RESORT }\end{array}$ & 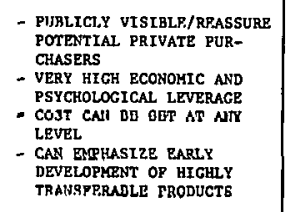 & $\begin{array}{l}\text { - MAY BE EXPENSIVE } \\
\text { - ADMINISTRATION MAY BE } \\
\text { CORPLEX } \\
\text { - MAY RESULT IN RRODUCTS } \\
\text { URISUITABLE TO PRIVATE } \\
\text { MARKBTS }\end{array}$ \\
\hline $\begin{array}{l}\text { ACCRRSSIVE FEDERAL } \\
\text { RESSEARCH AND } \\
\text { DEVELOPMENT PIOOCRAM }\end{array}$ & $\begin{array}{l}\text { - FUNDING FOR RESEARCH } \\
\text { AND DEVELOPHENT }\end{array}$ & $\begin{array}{l}\text { - GOVERNRENT GRANTS, CON- } \\
\text { TRATS, LOANS, PRDA'S } \\
\text { - AMTHTSTRRED BY DOR, } \\
\text { MATIONAL LABS, SRRT }\end{array}$ & $\begin{array}{l}\text { - LOW COST, LOW RISK } \\
\text { - GOVERRRENT CONTROL OP } \\
\text { RED POCUS } \\
\text { - GOVRRMYRNT CONI'KOL OP } \\
\text { DISSEMINATION OF RESULTS }\end{array}$ & $\begin{array}{l}\text { - DIFPICULT TO ASSESS COST- } \\
\text { EPFECT IVENESS }\end{array}$ \\
\hline
\end{tabular}

